\title{
Does Educational Background Affect CEO Compensation And Firm Performance?
}

\author{
Terrance Jalbert, University of Hawaii at Hilo, USA \\ Kimberly Furumo, University of Hawaii at Hilo, USA \\ Mercedes Jalbert, The Institute for Business \& Finance Research, USA
}

\begin{abstract}
This paper examines the educational background of Chief Executive Officers (CEOs) from large U.S. firms. Forbes CEO compensation lists and Compustat data covering 500 or more firms annually are utilized in the analysis for the period 1997-2006. Universities are ranked based on the number of graduates placed in top CEO positions and of the total compensation their graduates earn as CEO. Results show a select group of schools educate a large proportion of top CEOs. Harvard dominates the CEO market at all educational levels. Results show low correlation between university placement rankings and compensation rankings. Regressions on CEO compensation provide additional insights into CEO compensation determinants. Regressions of CEO educational variables on firm performance measures identify links between CEO education and firm performance. This is the first known paper to examine CEO gender as a determinant of compensation and firm performance. The evidence here provides hiring and compensation committees valuable information on appropriate hiring, retention and compensation strategies. It also provides government officials additional insights for designing appropriate regulations.
\end{abstract}

Keywords: CEO Compensation; CEO Education; CEO Gender; Firm Performance

\section{INTRODUCTION}

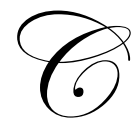

EO compensation and its relationship to firm performance has been examined in conjunction with the literature of several disciplines. This paper extends the analysis by examining educational backgrounds of CEO's from large U.S. companies. Specifically, this research examines educational backgrounds of CEO's from the largest U.S. firms over a ten-year time period from 1997-2006. A variety of studies document links between educational background and individual characteristics. Dollinger (1984) identified a relationship between education and tolerance for ambiguity. Other researchers have identified relationships between educational level, the rate of corporate innovation and the likelihood of strategic change (Bantel and Jackson, 1989 and Wiersemana and Bantel, 1992). Hambrick and Masson (1984) argued that advanced education both indicates and encourages a preference for administrative complexity. Still others have suggested that educational background provides a basis for psychological group identification that can create the perception of similarity regardless of any actual behavioral similarities (Tsui, Egan and O’Reilly, 1992).

Despite a large body of evidence that links educational background to a variety of attitudes and managerial behaviors, a relatively small body of literature examines educational background as it relates to CEO performance. Even fewer studies use large datasets to test their contentions. Jalbert Rao and Jalbert (2002) examine Forbes CEO compensation data from 1987-1996 including a dataset of some 8,000 observations. They rank universities based on the number of degrees awarded to large-firm CEO's and found that a select group of universities are primarily responsible for educating large-firm CEOs. Princeton is identified as the largest provider of undergraduate degrees while Harvard far-and-away the largest provider of graduate degrees. A large proportion of CEOs earned their undergraduate and graduate degrees from different universities. Jalbert Rao and Jalbert (2002) also examine CEO compensation as it relates to the school attended, finding significant disparities between the number of students placed in CEO roles and the salaries their graduates earn in those roles. They find little evidence to suggest that firm 
performance is affected by the CEOs educational background.

The current research is a direct extension Jalbert Rao and Jalbert (2002). This study examines data for the subsequent ten years from 1997-2006. A great deal has changed in the CEO marketplace in the ten years since the Jalbert Rao and Jalbert (2002) study was completed including corporate scandals at Enron, Tyco, Worldcom and other firms as well as passage of the Sarbanes-Oxley Act of 2002. Moreover, companies that offer large CEO compensation packages are faced with increasing criticism. These events have changed relationships between stockholders, boards, employees and CEO's. Due to these significant changes, an additional look at CEO compensation and firm performance is warranted. This paper extends the literature in some instances by utilizing more recent data, in other instances by using a different dataset and it extends the general body of literature by examining different variables as they relate to CEO compensation and firm performance.

The remainder of the paper is organized as follows. In the next section, we discuss the literature related to executive compensation. This section is followed by a discussion of the data utilized in the paper and a presentation of some summary statistics. The paper continues with a presentation and discussion of the empirical results. Finally, the paper closes with some concluding comments.

\section{SECTION 2: LITERATURE REVIEW}

A plethora of articles have examined CEO performance and compensation. In this section we review selected articles from this body of literature. Jalbert, Jalbert and Perrina (2004) examined specific degrees earned by CEOs. Of interest is to determine if those with differing degrees, such as an MBA, are more likely to be the CEO of a large firm. They found a large proportion of firms are managed by CEOs whom earned an MBA. They further found those with differing degrees have been with the firm for differing numbers of years, earned their undergraduate and graduate degrees at different ages, started working for the firm at different ages, became the CEO at differing ages, and were with the firm for differing lengths of time prior to becoming the CEO.

Gottesman and Morey (2006) examined the relationship between quality of Chief Executive Officer (CEO) education and firm performance using EXECUCOMP data. They find no evidence that firms with CEOs from more prestigious schools, as measured by average SAT and GMAT scores, outperform those from less prestigious schools. They also find that firms managed by CEOs with MBA or law degrees perform no better than firms with CEOs that do not have a graduate degree. They find some evidence that firms led by CEOs with non-MBA, nonlaw graduate degrees have slightly better risk-adjusted market performance than other firms. Finally, they find that compensation is somewhat higher for CEOs who attended more prestigious schools. This paper extends this work by examining a different, larger, dataset and controlling for different variables.

Collier and Wilson (1994) surveyed Chief Financial Officers of Fortune 1,000 companies on their educational choices. They find undergraduate work was spread among a larger number of schools than graduate education. When asked about their educational choices, they found that retrospective preferences were similar to actual choices.

Palia (2000) examined how educational background of a CEO impacts the types of firms they are selected to manage. He compared the performance of individuals that earned their degree from top undergraduate or graduate schools to those who earned their degree from less prestigious schools. They found managers with lower quality educational backgrounds manage firms in regulated industries, while those with higher quality educational backgrounds manage firms in unregulated industries. Other papers that address this issue include Joskow, Rose and Shephard (1993) and Jensen and Murphy (1990).

Hambrick and Masson (1984), and Capenter, Geletkanycz and Sanders (2004), discussed the role of management team homogeneity as it relates to decision making speed. The general argument is that homogeneous top management teams make strategic decisions more quickly and are more profitable than heterogeneous teams in stable environments. Westphal and Zajac (1995) examined 413, Fortune 500, companies and found that boards of directors prefer CEO's who are demographically similar to themselves including on an educational basis. Greater similarity between board members and CEO demographics result in higher CEO compensation. This body of 
literature suggests that CEO selection should focus on individuals that provide homogeneity among the leadership team.

Chevalier and Ellison (1999) examined educational backgrounds and other demographic variables of mutual fund managers. They measured university quality based on average SAT score of the manager's undergraduate university. They find that funds whose managers are from better quality universities outperform funds managed by other managers on a risk adjusted basis.

Barker and Mueller (2002) examined how CEO background is related to R\&D spending. They found the amount of CEO education does not impact R\&D spending for CEO's with a bachelor's degree. However, significant R\&D spending increases are found at firms where the CEO has an advanced science degree.

Gabaix and Landier (2008) addressed the question of why CEO pay has increased so much. Their findings indicate that increases in CEO pay from 1980 through 2003 can be fully attributed to a sixflold increase in market capitalization of large companies during the same period. They further found a small difference in CEO talent justifies large pay differences. Hermalin (2005) argues that CEO compensation increases can be explained by improved corporate governance. Higher pay is required to compensate for the increased chance of being fired.

Palia and Ravid (2002) examined differences between founding CEO's and non-founder CEO's. They developed and tested a model where founders work harder and become endogenously entrenched. They found that founders tend to be less responsive to performance incentives. They also found that founder run firms are more profitable. However, they found that firms led by family members of the original founders had lower market values. Fahlenbrach (2009) found that firms managed by a founder invest more in R\&D, have higher capital expenditures and made more focused mergers and acquisitions. He also found that after controlling for a number of factors, investing in founder managed firms produced a 4.4\% annual abnormal return. Jalbert and Jalbert (2005) also compared founding CEO's to non-founding CEO's. The evidence shows that founders draw a substantially higher compensation than their non-founder counterparts, but this difference depends upon the academic degrees that the individuals hold. Moreover the authors found significant differences between founders and non-founders in the ages when CEOs earned their degrees, age at which they started working for the company and age at which they become CEO. Founders tend to finish their degrees prior to entering the work force, while non-founders tend to enter the workforce prior to earning their degree.

\section{SECTION 3: DATA AND METHODOLOGY}

Each year since 1973, Forbes magazine has published a list containing information about the CEO's of large United States companies. Specifically, Forbes examines compensation and as many as thirty other variables for as many as 800 CEOs each year. In 2002, the number of firms included in the analysis was reduced to 500 . Firms included in the list are identified based on several firm size measures. The Forbes list contains background and compensation information about each firm's CEO. The Forbes compensation list is the foundation for this study. Some of the data utilized in this study were obtained in electronic format from Forbes, while others were obtained from lists presented on the Forbes website. Since 1987, Forbes has published information on the university the $\mathrm{CEO}$ attended. This educational background information is of interest in this paper.

A previous study in this series examines data prior to 1997. To avoid repetition, data for this paper is limited to the ten year period 1997-2006 including 6,305 annual observations. The number of observations in each year are presented in Table 1. Observations numbers do not remain constant in each year because Forbes reduced the number of firms included in the list as noted above. Reducing the data to an equal sample size in each year would have been optimal due to the unequal sample sizes across year. Unfortunately an unbiased reduction was not possible because Forbes does not report the criteria that it used to select firms for inclusion in the sample. 
Table 1*: Sample Statistics

\begin{tabular}{|c|c|}
\hline Year & Forbes Observations \\
\hline 1997 & 800 \\
\hline 1998 & 800 \\
\hline 1999 & 892 \\
\hline 2000 & 812 \\
\hline 2001 & 501 \\
\hline 2002 & 500 \\
\hline 2003 & 500 \\
\hline 2004 & 500 \\
\hline 2005 & 500 \\
\hline 2006 & 500 \\
\hline Total & 6,305 \\
\hline
\end{tabular}

This table shows data on the sample analyzed in this paper. The column labeled Forbes Observations indicates the number of CEOs listed in the Forbes Dataset.

For thirty-six observations, the data indicated the CEO had a graduate degree, but did not have an undergraduate degree suggesting obvious missing data. An internet search was conducted to complete the dataset. Data for eighteen observations were identified in this manner. The remaining observations were coded as missing data.

In order to facilitate additional tests, each firm in the Forbes list was matched with its corresponding ticker symbol and matched with corresponding data from Standard and Poor's Compustat.

The analysis considers two sets of dependent variables and two sets of independent variables. These variables are discussed in the following two sections.

\section{Dependent Variables}

The first set of dependent variables measure compensation earned by the CEO. Of interest in this paper is the extent to which university attended impacts the compensation that a CEO earns. While the Jalbert, Rao and Jalbert (2002) study was limited to examining total compensation, this study examines three measures of compensation. Total compensation, $T C$, is the total compensation provided by the firm to the CEO as obtained from Forbes. It includes salary, bonus, stock compensation and other compensation. Total compensation indicates the reward CEOs receive for all activities performed for the firm. These activities include managing the firm as well as providing capital for the firm. Salary, $S A L$, and salary plus bonus $S B$, variables are analyzed to identify the impact of education on various components of service provided by the CEO. By eliminating the non-salary and not-bonus elements of total compensation, these variables eliminate rewards for investment activities from the analysis. These two variables measure the return to human capital. Murphy (2003) and Murphy and Hall (2002), among others, have documented the importance of differentiating between compensation components.

The second set of dependent variables measure CEO performance. A great deal of research examines the relationship between CEO compensation and various performance measures. Many individuals argue that CEO compensation is excessive. However, if higher paid CEO's produce superior returns for investors, large compensation packages are justified. This paper examines the extent to which school attended impacts firm performance. Return on Assets, ROA, Return on Equity, ROE, and Return on Investment, ROI, measure firm performance in this study.

\section{Independent Variables}

The analysis considers four groups of independent variables. The first group measures CEO educational background. UGATT and GATT indicate if the CEO earned an undergraduate or graduate degree respectively. In each case, values of one and zero indicate the CEO did, or did not, earn the degree respectively. A second set of education variables indicate the school attended. Universities are classified based on the number of CEO's 
graduating from the institution. The variable TOP1U indicates the university that provided an undergraduate education to the largest number of CEOs. TOP5U indicated the five universities that provided an undergraduate education to the largest number of CEOs. Similarly, TOP10U, TOP25U and TOP50U indicate top 10, 25 and 50 undergraduate universities respectively. Variables are also developed for graduate school rankings, TOPlGTOP5OG and combined rankings, TOPIC-TOP5OC.

A second group of independent variables measure other demographic characteristics of the CEO. Wiersema and Bantel (1992), established that demographic attributes of CEOs affected firm performance and the firm's business decisions including youth, tenure, educational level, and functional background. The second group of independent variables capture the effects of CEO demographic characteristics. Lucier, Schuyt, and Spiegel (2003) found that individuals average 50 years of age when promoted to the CEO position. Berry, Bisjak, Lemmon, and Naveen (2000) found that average CEO age is about 56.7 years. Murphy and Zimmerman (1993) found that CEOs tend to leave their appointments at ages 64 and 65. Sundaram and Yermak (2007) and Wesphal and Zajac (1995) found a negative relationship between CEO age and attitude toward risk. Thomas and Peyrefitte (1996) found older CEOs have a positive impact on firm performance, after controlling for the affects of industry. Jalbert Rao and Jalbert (2002) found a positive relationship between CEO age and compensation but no relationship between CEO age and firm performance. Barro and Barro (1990) found that the pay-performance sensitivity of bank CEOs diminished with CEO experience. Contrasting these findings are Brick Palmon and Wald (2003), who found that age is not significant in explaining compensation. To measure the impact of CEO age on compensation and performance, the variable $C E O A G E$, is incorporated in the analysis.

Brick, Palmon and Wald (2003) found experience was positively related to compensation. Jalbert Rao and Jalbert (2002) found a negative relationship between years with the firm and CEO compensation and argue their findings indicate salary compression among CEOs. Kato and Rockel (1992b) found that Japanese CEO's are with the firm longer than U.S. CEOs prior to becoming CEO. To identify how experience affects compensation and performance, we include two experience variables in our analysis. The first variable, the number of years a CEO has been with the firm, YRSCO measures firm specific experience. The second variable, the number of years the individual has served as CEO, measures experience in their current role.

Fahlenbrach (2004) found that firms managed by a founder had higher capital expenditures, made more focused mergers and acquisitions, and provided positive abnormal returns to their investors. Jalbert, Rao and Jalbert (2002) and Jalbert and Jalbert (2005) found that founder CEO's earned higher total compensation than their nonfounder counterparts. However, the results of Palia, Ravid and Wang (2008), He (2008) and others contradict these findings. Their evidence indicates that non-founding CEO's earn more than founders. Some founders have even been known to take a token $\$ 1$ in annual compensation (Plitch, 2005). While the evidence on founder pay is mixed, the evidence strongly suggests that founder managed firms outperform non-founder managed firms. Jalbert, Rao and Jalbert's (2002) results indicate that founders on average provided a seven percent higher ROA than other CEOs. Fahlengrach's (2005) results show that founder CEO's achieved an $11 \%$ higher return for investors. Adams, Almeida and Ferreira (2009) use an instrumental variables approach, also finding a positive relationship between CEO founder and performance. To capture the effect that a founding CEO has on the firm, the variable FOUNDER is included in the analysis indicating if the current CEO founded the firm.

While the issue of compensation differences by gender has been examined extensively in the literature, no known study has examined the role of CEO gender in determining compensation or firm performance. A particular lack of evidence exists regarding gender differences at the highest CEO ranks. To measure the impact of gender on compensation and firm performance each observation was coded by CEO gender. In instances when gender was not clear from the name, company documents and an internet search were used to identify the gender. The variable GENDER is coded 1=Male and 2=Female.

The third set of independent variables measure the managerial behavior of CEOs. CEOs exert exclusive or significant control over a number of managerial issues. Capital structure represents one such variable. Modigliani and Miller (1958) wrote the seminal article on capital structure. Since then, many articles have extended this line of literature including Modigliani and Miller (1963); Miller (1977); DeAngelo and Masulis (1980); and Jalbert (2002). One line of literature suggests that the structure of CEO compensation should be a function of firm risk, leverage, 
size, and growth opportunities of the firm (Aggarwal and Samwick, 1999; and Prendergast, 2002). John and John (1993) found a negative relationship between pay-performance sensitivity and leverage. To capture issues associated with leverage the long term debt to equity ratio, $L T D E$, of the firm is incorporated in the analysis.

CEOs are also instrumental in determining dividend policies. Miller and Modigliani (1961) proposed an irrelevance theory suggesting that in an idealized world, dividends do not affect firm value. Many authors have extended this work. One line of literature focuses on the role of dividends in monitoring firm managers (Easterbrook, 1984). Bhattacharyya, Mawani and Morrill (2008a and 2008b) find a negative relationship between dividend payout and executive compensation among Canadian and U.S firms. The dividend payout ratio of the firm, PAYOUT, is incorporated into the analysis to capture these effects.

The relationship between firm size and a variety of firm characteristics and performance issues is well established. Identification of the size effect as it relates to stock returns is generally attributed to Banz (1981) and Reinganum (1981). More recent studies examine the relationship between firm size and CEO compensation (see Jalbert, Rao and Jalbert, 2002; Gibbons and Murphy, 1992; Baker Jensen and Murphy, 1988 and Baker and Hall, 2002). The general findings are that CEOs of larger firms earn more money. The analysis here incorporates total assets, ASSETS, as a measure of firm size.

Jensen and Meckling (1976) wrote the seminal article on the relationship between proportion of the firm owned by an employee and his/her motivations. They argued that increasing the proportion of the firm owned by managers aligned the managers' interests with those of the shareholders. Fama (1980), on the other hand, argued that a properly functioning labor market for managers served to minimize agency problems. The percentage of the company owned by the CEO, $P O W N$, is included in the analysis to capture ownership structure effects.

Baker, Jensen, and Murphy (1988) argued that promotion based reward systems are only effective in growing firms. They provided evidence of a positive relationship between sales growth and CEO compensation. Gabaix and Landier (2008) found evidence to suggest that increases in CEO pay can be largely attributable to increases in firm size. Murphy (1985) found that after controlling for firm size a ten percent firm growth rate implies a CEO compensation increase of between 2 and 3 percent. To capture the effects of growth on CEO compensation and performance sales growth, SGROW, is included in the analysis.

Jensen (1986a, 1986b) argued that managers are improperly motivated in firms with slow growth but free cash flow. In these instances, promotion based reward systems encourage managers to undertake unprofitable growth opportunities rather than pay dividends. Jensen (1986a) argued that information asymmetries between managers and owners motivate managers to over-invest. Free cash flows are used for unprofitable investments which increase managerial utility. Broussard, Buchenroth and Pilotte (2004) found evidence that pay for performance reduces underinvestment of cash flows due to managerial shirking. To capture the impact of cash flows on CEO compensation and performance free cash flow, $F C F$, is included in the analysis.

Evidence on the relationship between CEO compensation and stock returns is mixed. Pennathur and Shelor (2002) identified a positive relationship between CEO compensation and stock returns in the real estate industry. Dechow (2006) found that CEO pay is more sensitive to negative stock returns than positive stock returns. Bebchuck, Cremers and Peyer (2009), examined CEO compensation relative to the five highest paid executives in the firm, finding that larger CEO pay proportions are associated with lower firm value, lower profitability and lower stock returns. Cooper, M.J. H. Gulen and P. R. Rau (2009) found that CEO pay is negatively related to future shareholder wealth changes. The firms with CEOs in the top ten percent of pay earned $13 \%$ negative abnormal returns over the subsequent five years. In this study, we incorporate two measures of stock returns. One year returns, ONEyrRET, measures the current relationship between compensation and performance and THyrRET, three year returns, measures the relationship between compensation and longer term performance.

A final group of independent variables control for other factors that may affect CEO compensation. Beaty and Zajac (1994) found the use of executive compensation contracts to motivate managers is limited by managerial risk aversion. Sundaram and Yermak (2007) and Wesphal and Zajac (1995) found a negative relationship between CEO age and attitude toward risk. Many others have documented a relationship between firm performance and 
various measures of risk. Here, two measures of risk are incorporated into the analysis. Fama and French (1993 and 1995) proposed book-to-market as a measure of risk. We incorporate the price-to-book ratio, PtoB, in our model. In addition we incorporate a new measure of risk, earnings stability, ESTAB, into the model that is available from Compustat. The Compustat earnings stability score ranks firms from 1 to 5 based on the stability of their earnings.

It is well known that firms in different industries operate differently and compensate their CEO's differently. Datta and Guthrie (1994) suggested that industry specific experience is essential for CEOs. Roach and Goedde (2003) examined CEO compensation in the pharmaceutical industry. John, Saunders and Senbet, 2000; and Hermalin and Wallace, 2001 examined CEO compensation in the banking industry and Barragato (2002) examined executive compensation in the hospital industry. Each of these studies noted peculiarities of executive compensation based on industry. Joskow, Rose and Wolfram (1996) show that political and regulatory constraints had an effect on CEO compensation in utility industries. Rajagopalan and Datta (1996) found that industry plays a limited role in explaining variations in CEO demographics. To control for industry effects, the firms were classified by two-digit industry sector codes. A categorical variable of industry sectors was included in the regression models.

Gabaix and Landier (2008) Hermalin (2005) documented time varying changes in compensation. Inflation, changing economy-wide fortunes, political pressure, regulations and other exogenous time varying factors have been found to impact compensation and firm performance. A time indicator, YEAR, is included to control for changes in compensation over time.

\section{SECTION 4: UNIVERSITY RANKINGS}

This section presents two university rankings. The first is based on the number of graduates that a university has placed in a top CEO position and the second is based on the average compensation of graduates that become a top CEO.

\section{Ranking by University Attended}

Table 2 presents university rankings by number of graduates placed in top CEO positions. Schools placing more of their graduates in top CEO positions rank higher. The first set of columns ranks schools based on undergraduate degrees conferred. The second set of columns ranks universities based on graduate degrees conferred. The third set of columns ranks universities based on conferring either an undergraduate or a graduate degree to a top CEO.

The undergraduate rankings are reported in Panel A of Table 2. Of 6305 total observations, 5,782 observations involved a CEO that earned an undergraduate degree. From the remaining 523 observations, 505 observations involved a CEO that did not hold an undergraduate degree, and undergraduate information was not available for eighteen observations. Four hundred eighty eight institutions were responsible for providing an undergraduate education to at least one CEO. The undergraduate analysis indicates a very clear pecking order for selection as a CEO of a major U.S. company. Harvard is responsible for providing an undergraduate education to 210 observations, about 3.3 percent of all CEOs and about 3.6 of CEOs that had a degree. Overall, the rankings differ considerably from those presented in Jalbert, Rao and Jalbert, 2002. For example in the undergraduate rankings, Yale improves in ranking from 6th to second, and University of Wisconsin improves in ranking from 13th to fourth place.

Table 3 presents additional details on the proportion of CEOs educated by various groups of schools. The top five schools provided an undergraduate education for 677 observations, about 10.7 percent of all CEOs and 11.7 of CEOs that had a degree. The top ten schools provided an undergraduate-educated 1084 observations representing 17.2 percent of all CEOs and 18.7 percent of CEOs with an undergraduate degree. 
Table 2*: Educational Background by School

\begin{tabular}{|c|c|c|c|c|c|c|}
\hline \multirow[b]{2}{*}{ Rank } & \multicolumn{2}{|c|}{ Panel A: Undergrad Schools } & \multicolumn{2}{|c|}{ Panel B: Grad. Schools } & \multicolumn{2}{|c|}{ Panel C: Undergrad and Grad. } \\
\hline & School & $\mathbf{N}$ & School & $\mathbf{N}$ & School & $\mathbf{N}$ \\
\hline & Total Observations & 6,305 & Total Observations & 6.305 & Total Obs. & 6,305 \\
\hline & No Undergrad Ed & 500 & No Graduate Ed & 2,660 & No UG or No G & 500 \\
\hline 1 & Harvard & 210 & Harvard & 601 & Harvard & 722 \\
\hline 2 & Princeton & 142 & Stanford & 188 & Pennsylvania & 240 \\
\hline 3 & Stanford & 118 & Pennsylvania & 160 & Stanford & 239 \\
\hline 4 & Wisconsin Madison & 109 & Columbia & 152 & Princeton & 183 \\
\hline 5 & Pennsylvania & 98 & MIT & 105 & Columbia & 161 \\
\hline 6 & Yale & 89 & Northwestern & 95 & MIT & 139 \\
\hline 7 & Dartmouth & 81 & Chicago & 92 & Yale & 129 \\
\hline 8 & Cornell & 80 & NYU & 85 & NYU & 127 \\
\hline 9 & CUNY City & 79 & Virginia & 82 & Northwestern & 120 \\
\hline 10 & Purdue & 78 & USC & 55 & Wisconsin & 115 \\
\hline 11 & Notre Dame & 77 & Texas & 50 & Virginia & 110 \\
\hline 12 & Texas & 74 & Michigan & 50 & Dartmouth & 107 \\
\hline 13 & Duke & 69 & Dartmouth & 48 & Texas & 103 \\
\hline 14 & North Carolina & 63 & Indiana & 48 & Cornell & 100 \\
\hline 15 & U.S. Naval Academy & 61 & Yale & 42 & Chicago & 95 \\
\hline 16 & Alabama & 59 & Princeton & 41 & Purdue & 91 \\
\hline 17 & Missouri & 57 & Rutgers & 39 & CUNY City & 86 \\
\hline 18 & Northwestern & 57 & George Washington & 38 & Duke & 83 \\
\hline 19 & Washington & 57 & Wisconsin & 36 & USC & 79 \\
\hline 20 & UCLA & 53 & Cornell & 34 & Michigan & 79 \\
\hline 21 & Rutgers & 47 & Case Western & 30 & Notre Dame & 77 \\
\hline 22 & MIT & 46 & UCLA & 30 & Washington & 71 \\
\hline 23 & NYU & 45 & Purdue & 29 & Rutgers & 70 \\
\hline 24 & Denison & 44 & Boston U. & 28 & UCLA & 69 \\
\hline 25 & Ohio State & 43 & Houston & 28 & North Carolina & 64 \\
\hline 26 & Colorado & 41 & Washington & 27 & U.S. Naval Academy & 61 \\
\hline 27 & Georgia & 41 & Wisconsin-Milwaukee & 26 & Alabama & 60 \\
\hline 28 & Iowa & 41 & Xavier & 25 & Indiana & 57 \\
\hline 29 & Auburn & 40 & Berkeley & 24 & Missouri & 57 \\
\hline 30 & Lehigh & 40 & Georgetown & 24 & Illinois & 56 \\
\hline 31 & Utah & 40 & Pace & 24 & Vanderbilt & 53 \\
\hline 32 & Michigan & 40 & Illinois & 23 & Ohio State & 51 \\
\hline 33 & Illinois & 40 & Loyola & 23 & Colorado & 48 \\
\hline 34 & Fordham & 39 & SMU & 23 & Villanova & 48 \\
\hline 35 & USC & 38 & Villanova & 22 & Minnesota & 46 \\
\hline 36 & Vanderbilt & 36 & Syracuse & 21 & Boston U & 45 \\
\hline 37 & Pittsburgh & 34 & Duke & 20 & Fordham & 45 \\
\hline 38 & Virginia & 33 & DePaul & 20 & Denison & 44 \\
\hline 39 & Villanova & 33 & Georgia State & 19 & George Washington & 43 \\
\hline 40 & Minnesota & 32 & Minnesota & 19 & SMU & 43 \\
\hline 41 & U.S. Military Acad. & 31 & Pittsburg & 19 & Georgia & 42 \\
\hline 42 & Williams College & 31 & Florida & 18 & Iowa & 41 \\
\hline 43 & Georgia Tech & 30 & Pepperdine & 18 & Loyola (IL) & 41 \\
\hline 44 & Miami U. Ohio & 30 & Wake Forest & 18 & Michigan State & 41 \\
\hline 45 & Michigan State & 30 & Michigan State & 17 & Pittsburgh & 41 \\
\hline 46 & Northeastern & 30 & Vanderbilt & 17 & Auburn & 40 \\
\hline 47 & Penn State & 30 & CUNY City & 17 & Georgetown & 40 \\
\hline 48 & Arizona & 29 & Creighton & 16 & Lehigh & 40 \\
\hline 49 & Manhattan College & 29 & Denver & 16 & Tufts & 40 \\
\hline 50 & Brown & 28 & Emory & 16 & Utah & 40 \\
\hline & Oklahoma State & 28 & Brooklyn Law & 16 & Wisconsin - Milwaukee & 40 \\
\hline & SMU & 28 & Washington U. & 16 & & \\
\hline & Texas A\&M & 28 & & & & \\
\hline & Tufts & 28 & & & & \\
\hline & Top 50 Total & $2,802^{*}$ & Top 50 Total & 2,698 & Top 50 Schools & 4,623 \\
\hline & Other Schools & 2,980 & Other Schools & 947 & Other Schools & 3,929 \\
\hline & Missing Observations & 23 & & & & 23 \\
\hline
\end{tabular}

This table ranks universities based on the number of graduates who managed one of the largest U.S. firms. Column A ranks universities based on undergraduate degrees conferred. Panel B ranks universities based on graduate degrees conferred. Panel C ranks universities based on providing either an undergraduate or graduate degree to a student. * Five Universities tied for the $50^{\text {th }}$ ranking in the undergraduate education listing. 
When comparing the results here with those of Jalbert, Rao and Jalbert (JRJ) (2002), over the most recent ten years, Harvard has replaced Princeton as the number one provider of undergraduate education for these individuals. Moreover, the number one school has taken on increasing importance over the past ten years. In the earlier study, the top school educated 3.3 percent of all CEOs, increasing to 3.6 percent in the current study. The top $5,10,25$ and 50 schools have taken on a slightly lower importance. The percentage of CEOs educated by these schools has declined by 2 to 5 percent over the past ten years.

Panel B of Table 2 presents the graduate school findings. The results indicate that 3,643 observations involved a CEO that earned a graduate degree. Two hundred thirty six different institutions were responsible for providing a graduate education to at least one CEO. Harvard is the clear leader in providing graduate education having educated the CEOs of 600 observations, $9.5 \%$ of all CEOs and $16.4 \%$ of CEOs that have a graduate education. While Harvard is clearly the heavyweight, it has decreased in importance slightly over the past ten years. Summary statistics are presented in Table 3. The impact of the largest five and ten schools is amazing at 19.1 and 33.1 percent of all CEO's respectively. The impact is even more pronounced when limiting the analysis to those individuals that have a graduate degree, with the top 10 schools educating 44.2 percent of all CEO's with a graduate degree. The top 50 schools are responsible for providing a graduate education to an amazing70 percent of those CEOs that hold a graduate degree.

Next, a combined analysis is completed, identifying whether an individual earned either their undergraduate or graduate degree from a particular institution. Regardless of the degree earned at a school, the individual would have a similar network of friends and similar access to placement services. As such, university affiliation may be more critical to achieving the CEO career level than the particular degree earned from the university. In this analysis we count an individual if they have earned either their graduate or undergraduate degree from a university and rank schools based on the combined degrees conferred. To complete this analysis, the undergraduate and graduate lists were combined, resulting in 12,610 observations. To avoid double counting, duplicate entries for individuals who received both the undergraduate and graduate degrees from the same institution were deleted. Specifically, when the undergraduate school and graduate school for a CEO were the same, the graduate school entry was deleted. This procedure resulted in 875 deleted observations. Next, the 2,660 observations that did not have an undergraduate degree, and an additional 500 that did not have any higher education were deleted. Finally, the 23 missing observations noted earlier were deleted. This procedure netted 8,552 unique contributions to the CEO's educational experience. Of the 6305 observations 3643 involved an individual that attended graduate school of which, 2,768 earned their undergraduate and graduate degrees at different institutions.

Panel $\mathrm{C}$ of Table 2 shows the combined analysis results. The rankings again clearly demonstrate the importance of Harvard University in educating CEOs. Harvard is responsible for providing either an undergraduate or graduate degree to the CEO associated with 722 observations. Some statistics on the significance of this figure are presented in Table 3. This 722 figure represents 11.5 percent of all CEOs and 12.5 percent of CEOs having a college degree. Harvard increased its importance over the past 10 years from 11.1 and 12.1 percent respectively.

Table 3: Summary of Top School Representation

\begin{tabular}{|c|c|c|c|c|c|c|c|c|c|}
\hline & \multicolumn{3}{|c|}{ Undergrad } & \multicolumn{3}{c|}{ Graduate } & \multicolumn{3}{c|}{ Graduate or Undergraduate } \\
\hline School & Count & $\begin{array}{c}\text { All } \\
\text { CEO's }\end{array}$ & $\begin{array}{c}\text { With } \\
\text { degree }\end{array}$ & Count & $\begin{array}{c}\text { All } \\
\text { CEO's }\end{array}$ & $\begin{array}{c}\text { With } \\
\text { Degree }\end{array}$ & Count & $\begin{array}{c}\text { All } \\
\text { CEO's }\end{array}$ & $\begin{array}{c}\text { With } \\
\text { Degree }\end{array}$ \\
\hline Top School & 210 & 3.3 & 3.6 & 601 & 9.5 & 16.5 & 722 & 11.5 & 12.5 \\
\hline Top 5 School & 677 & 10.7 & 11.7 & 1206 & 19.1 & 33.1 & 1545 & 24.5 & 26.7 \\
\hline Top 10 School & 1084 & 17.2 & 18.7 & 1615 & 25.6 & 44.3 & 2175 & 34.5 & 37.6 \\
\hline Top 25 School & 1936 & 30.7 & 33.5 & 2186 & 34.7 & 60.0 & 3459 & 54.9 & 59.8 \\
\hline Top 50 School & 2801 & 44.4 & 48.4 & 2698 & 42.8 & 74.0 & 4623 & 73.3 & 80.0 \\
\hline All Others & 2980 & 47.2 & & 947 & 15 & 25.9 & 1159 & 18.3 & 20.0 \\
\hline Did Not Earn & 500 & 7.9 & & 2660 & 42.2 & & 500 & 7.9 & \\
\hline Missing Obs. & 23 & 0.5 & & 0 & 0 & & 23 & 0.5 & \\
\hline
\end{tabular}

This table shows the percentage of CEO's produced by schools with different ranks. 
Table 4: Total Compensation By School in 2006 dollars

\begin{tabular}{|c|c|c|c|c|c|c|}
\hline \multirow[b]{2}{*}{ Rank } & \multicolumn{2}{|c|}{ Panel A: Undergrad Schools } & \multicolumn{2}{|c|}{ Panel B: Grad. Schools } & \multicolumn{2}{|c|}{ Panel C: Undergrad and Grad. } \\
\hline & School & Comp. & School & Comp. & School & Comp. \\
\hline & No Undergrad Ed & 13,390 & No Graduate Ed & 9,573 & UG but no Grad & 8,595 \\
\hline 1 & CUNY Queens & 59,207 & CUNY City & 44,866 & CUNY Queens & 59,207 \\
\hline 2 & American U Beirut & 54,355 & Illinois & 27,532 & Middlebury C & 41,539 \\
\hline 3 & Middlebury C & 41,539 & USC & 26,945 & Williams C & 36,950 \\
\hline 4 & Pace U NY & 41,069 & Boston U & 20,737 & SUNY Buffalo & 35,621 \\
\hline 5 & Long Is. U & 38,703 & Yale & 15,009 & American U Beirut & 33,061 \\
\hline 6 & Williams C & 36,950 & NYU & 14,816 & Long Is. U & 30,337 \\
\hline 7 & U of Massachusetts & 30,171 & U of Minnesota & 14,655 & Denison & 28,238 \\
\hline 8 & Denison & 28,238 & Indiana U & 13,736 & U of Massachusetts & 25,329 \\
\hline 9 & West Virginia & 22,038 & Widener U & 13,157 & West Virginia & 22,038 \\
\hline 10 & U of Colorado & 18,619 & U of Washington & 13,123 & CUNY City & 21,022 \\
\hline 11 & Cornell & 18,408 & U of Penn-Wharton & 12,935 & USC & 20,172 \\
\hline 12 & NYU & 18,285 & Stanford & 12,389 & Boston & 19,589 \\
\hline 13 & Boston & 17,700 & Colorado & 10,868 & Pace U NY & 19,039 \\
\hline 14 & Texas Tech & 17,214 & Princeton & 10,717 & Colorado & 18,236 \\
\hline 15 & Loyola Marymount & 16,875 & MIT & 10,643 & Illinois & 17,364 \\
\hline 16 & NC State & 16,330 & Houston & 10,509 & Miami & 17,339 \\
\hline 17 & Stanford & 15,933 & Virginia & 9,749 & Baylor & 16,777 \\
\hline 18 & Illinois & 13,902 & Chicago & 9,748 & Texas Tech & 16,364 \\
\hline 19 & CUNY City & 13,779 & Kentucky & 9,541 & NYU & 16,213 \\
\hline 20 & George Washington & 13,750 & Harvard & 9,446 & Cornell & 15,246 \\
\hline 21 & Bowdoin College & 13,350 & Berkeley & 9,284 & NC State & 15,229 \\
\hline 22 & Fordham & 13,292 & Columbia & 9,264 & Minnesota & 13,510 \\
\hline 23 & US Military Acad & 13,275 & George Washington & 9,081 & Bowdoin College & 13,350 \\
\hline 24 & Brigham Young & 13,181 & Drexel & 8,362 & US Military Acad & 13,275 \\
\hline 25 & Cleveland State & 12,431 & U of Rochester & 8,268 & Brigham Young & 13,181 \\
\hline 26 & Weber State & 12,300 & Pepperdine & 8,264 & Widener U & 13,157 \\
\hline 27 & Loyola U (IL) & 12,055 & U of Florida & 7,845 & Cleveland State & 12,431 \\
\hline 28 & Dartmouth & 12,041 & U of Denver & 7,790 & $\mathrm{U}$ of Memphis & 12,378 \\
\hline 29 & Minnesota & 11,701 & Duquesne & 7,549 & Weber State & 12,300 \\
\hline 30 & Mississippi & 11,602 & Rutgers & 7,519 & Indiana U & 12,252 \\
\hline 31 & William \& Mary & 11,478 & Wis Madison & 7,510 & Fordham & 12,224 \\
\hline 32 & Georgia State U & 11,471 & Wis Milwaukee & 7,396 & Western Illinois & 11,844 \\
\hline 33 & Villanova & 11,337 & Utah & 7,253 & Stanford & 11,562 \\
\hline 34 & UCLA & 11,107 & Case Institute of Tec & 7,221 & U of Pennsylvania & 11,521 \\
\hline 35 & Texas El Paso & 11,075 & Akron & 7,166 & Loyola C (Md) & 11,452 \\
\hline 36 & Rhode Island & 10,973 & Ohio State & 7,027 & Texas El Paso & 11,075 \\
\hline 37 & San Jose State U & 10,945 & Carnegie Mellon & 6,837 & William \& Mary & 10,725 \\
\hline 38 & Tufts U & 10,491 & Cornell & 6,658 & Dartmouth & 10,612 \\
\hline 39 & Mississippi State & 10,119 & Pace U NY & 6,410 & Mississippi State & 10,119 \\
\hline 40 & USC & 10,107 & Kansas & 6,305 & San Jose State & 9,935 \\
\hline 41 & Colgate U & 9,725 & Fairleigh Dickinson & 6,150 & Houston & 9,794 \\
\hline 42 & Wellesley C & 9,564 & Northwestern & 6,059 & MIT & 9,752 \\
\hline 43 & Washburn U & 9,285 & UCLA & 5,909 & Colgate & 9,725 \\
\hline 44 & SUNY New Paltz & 9,075 & Syracuse & 5,869 & Wellesley C & 9,564 \\
\hline 45 & Notre Dame & 9,056 & Tufts U & 5,697 & U of Chicago & 9,489 \\
\hline 46 & Pennsylvania & 8,751 & U of South Carolina & 5,680 & Harvard & 9,378 \\
\hline 47 & Indian Tech & 8,592 & Washington & 5,661 & Villanova & 9,365 \\
\hline 48 & Trinity College CT & 8,479 & Xavier & 5,652 & Washburn & 9,285 \\
\hline 49 & Georgia & 8,439 & Villanova & 5,562 & UCLA & 9,146 \\
\hline 50 & Union C & 8,433 & Michigan & 5,405 & U of Cal-Davis & 9,120 \\
\hline & Average Comp. & 9,300 & & & Grad \& UG Same Sch. & 8,295 \\
\hline & & & & & Grad \& UG Diff. Sch & 9,352 \\
\hline
\end{tabular}

This table ranks schools based on the inflation adjusted average total compensation of graduates in top CEO positions. The Same sch. and different school salary levels are not significantly different at the 10 percent level using a T-test for differences in means. Only universities that had eleven or more observations were considered for the analysis. The figures in each cell are in thousands of dollars.

Collectively, the top 50 schools provided either an undergraduate or graduate degree to 73.3 percent of all CEOs and 80 percent of those CEOs that possess a degree. These figures are down about three percent from the previous decade indicating that other schools are making some inroads in placing their graduates in top CEO 
positions. Nevertheless, it is clearly advisable for an individual who wishes to become the CEO of a large U.S. firm to gain admission to a top tier school.

\section{Ranking by Total Compensation}

In this analysis, we rank schools based on total compensation their graduates earn in top CEO positions. To complete this analysis we recomputed CEO total compensation to adjust for inflation. This computation is made to adjust the total compensation to constant 2006 dollars. Next, we compute the average annual total compensation earned by the CEOs from each university. Finally universities are ranked based on the adjusted total compensation figure. In completing the ranking universities that had fewer than 11 observations were eliminated from consideration. This procedure guarantees that at least two individual CEOs were involved in the average total compensation calculations.

The results are presented in Table 4. The figure in each cell is the inflation adjusted average compensation in thousands of dollars earned by graduates from each school. Similar to the previous table, Panel A reports the results for undergraduate degrees, Panel B reports the results for graduate degrees and Panel C reports the results for combined degrees. The results indicate a significant discrepancy between those schools that are outstanding at placing their graduates as denoted in Tables 2 and 3, and those whose graduates earn top dollar. Interestingly, despite its impressive numeric showing in the compensation list, Harvard did not make the top 50 undergraduate compensation listing. The remaining top ten schools from Table 2 fared little better. Only five of the top ten placement schools achieved the top 50 compensation list. No school was able to make the top ten on both lists. Stanford University is the highest ranked school to demonstrate consistency in both number of CEO's and average total compensation. Stanford ranked 3, 2 and 3 in CEO numbers and 17, 12, and 33 in compensation for the undergraduate graduate and combined analyses respectively.

CUNY Queens graduates draw far and away the largest compensation packages in the undergraduate and combined listings. The differences are particularly striking in the combined analysis. CUNY Queens graduates average total compensation is $\$ 59,207,000$ per year. Second place, Middlebury College graduates earned $\$ 41,539,000$ per year. Interestingly CUNY City graduate school graduates earn the highest compensation at $\$ 44,866,000$, well ahead of second place University of Illinois graduates that earned $\$ 27,532,000$ per year. CUNY places two schools among the top ten in the combined category, CUNY Queens and CUNY City.

Interestingly, CEOs that earned their undergraduate and graduate degrees from the same university earned $\$ 8,295,000$ on average while those that attended a different school for their undergraduate and graduate studies earned $\$ 9,352,000$ on average. Somewhat surprisingly, given the rather large average difference, a t-tests indicates that this difference is not significant at the ten percent level.

One particularly notable difference between this study and Jalbert, Rao and Jalbert, 2002 is the appearance of Long Island University in the Rankings. While Long Island University was not ranked in the earlier study, it enters the rankings in an impressive 5th place for undergraduate and combined rankings. Dickinson and Fairleigh Dickinson ranked 9th and 12th in the earlier study, but did not enter the top 50 rankings in this study.

\section{SECTION 5: EMPIRICAL RESULTS}

The empirical analysis begins by regressing each educational variable on each compensation variable. For example, the first regression in Table 5 regresses the possession of an undergraduate degree, UGATT, on total Compensation, $T C$, as follows:

$T C=\alpha+\beta_{1} U G A T T+\varepsilon$

The results from Equation 1 regressions are presented in Table 5. In Panels A, B and C each education variables is regressed on Total Compensation, Salary plus Bonus and Salary respectively. The first figure in each cell is the regression coefficient. The second figure in each cell is the t-statistic along with a significance indicator. $* * *, * *$ and $*$ indicate significance at the 1,5 and 10 percent levels respectively. The results in Panel A show that the coefficient on UGATT is negative and significant at the one percent level. This finding is consistent with those 
of Jalbert, Rao and Jalbert (2002), who also found that CEO's who do not have an undergraduate degree earn more than those that do. Several plausible explanations can be forwarded for this finding. It is possible that CEO's who do not attend school achieve their position because of family relationships or family stock holdings rather than their educational background. The undergraduate and combined university regressions show no significant explanatory power for total compensation. However, the graduate school regressions do have explanatory power with the Top10, Top25 and Top50 groups showing a significantly positive relationship.

Results from the regression on salary plus bonus appear in Panel B of Table 5. The results show that attending an undergraduate or graduate school are not significant in explaining salary plus bonus. However, attending a top university does impact the salary and bonus earned. The results are significant for top five and top ten undergraduate universities, each measure of quality graduate school as well as top one, ten and twenty-five combined universities.

Results from the regression on salary alone are presented in Table 5, Panel C. The results indicate that earning an undergraduate degree is significant in explaining salary, but earning a graduate degree is not significant. The results indicate that having attended the top undergraduate school (Harvard) is negatively significant in explaining salary. This indicates that Harvard graduates, while occupying many top CEO positions, earn a lower salary than their counterparts from other schools. No other undergraduate measures are significant in explaining salary. Each graduate school category has positive explanatory power for salary at the one percent level. The combined university categories explain salary positively and significantly with the exception of the top university.

Taken together, the evidence from Table 5 suggests that school attended, particularly the graduate school attended, impacts salary to a great extent. However, the results indicate that school attended impacts salary plus bonus and total compensation to a lesser degree. This is perhaps not surprising. Salary may be more related to the background of the CEO including universities attended. Bonus and Total Compensation may be more related to performance and stock investments in the firm.

To further examine this issue, a series of control variables are included in the compensation regressions. The estimated equation for the first column of results in Table 6 is:

$$
\begin{aligned}
\text { TC } \alpha+\beta_{1} U G A T T & +\beta_{2} \text { CEOAGE }+\beta_{3} \text { YRSCEO }+\beta_{4} Y R S C O+\beta_{5} \text { FOUNDER }+\beta_{6} \text { GENDER }+\beta_{7} \text { POWN } \\
& +\beta_{8} \text { YEAR }+\beta_{9} \text { INDUSTRY }+\beta_{10} \text { ASSETS }+\beta_{11} \text { LTDE }+\beta_{12} \text { ONEyrRET }+\beta_{13} \text { THyrRET } \\
& +\beta_{14} \text { FCF }+\beta_{15} \text { ROA }+\beta_{16} \text { PAYOUT }+\beta_{17} \text { SGROW }+\beta_{18} \text { ESTAB }+\beta_{19} \text { PRtoBK }+\varepsilon
\end{aligned}
$$

Results of regressions on total compensation are presented in Table 6. The columns present the results when various educational variables are substituted into Equation 2. The first two columns include the degree earned variables UGATT and GATT. Columns three through five provide an analysis for top undergraduate, graduate and combined schools respectively. The coefficients and significance of the control variables in the top school regressions were quite similar across measures. Thus, the control variables are presented only for the TOP 10 education variable. Coefficients for the education variables obtained from separate regressions are presented at the bottom of the table.

The results in Table 6 show that earning a degree or the quality of degree earned do not explain total compensation after controlling for other variables. Nevertheless, the control variables provide some insights. CEO age is positively significant in explaining total compensation. Older CEOs earn more than younger CEOs. Years with the company is not significant in explaining total compensation, a finding that contradicts those of Jalbert Rao and Jalbert (2002) who found a negatively significant relationship between years with the company and total compensation. Founder is significantly positive. The magnitude of the founder coefficient, exceeding 5,000, suggests that founders earn some $\$ 5$ million more than their non-founder counterparts. This finding is consistent with Jalbert, Rao and Jalbert (2002) who presented similar results. While the coefficient on GENDER is large, it is not significant. This could be the result of the relatively few female CEOs in the data, or indeed the absence of gender discrimination. 
Table 5: Regressions on Compensation Components

\begin{tabular}{|c|c|c|c|c|}
\hline \multicolumn{5}{|c|}{ Panel A: Total Compensation } \\
\hline Independent Variable & $\mathrm{N}$ & Intercept & Coefficient & T-Statistic \\
\hline UGATT & 6194 & $11,531.37$ & $-3,607.20$ & $-3.26^{* * *}$ \\
\hline GATT & 6199 & 8453.70 & -391.74 & -0.63 \\
\hline Top $1 \mathrm{U}$ & 6199 & 8255.20 & -914.01 & -0.53 \\
\hline Top 5U & 6199 & 8181.21 & 413.97 & 0.419 \\
\hline Top 10U & 6199 & 8045.67 & 1047.38 & 1.29 \\
\hline Top $25 \mathrm{U}$ & 6199 & 8154.39 & 232.03 & 0.350 \\
\hline Top 50U & 6199 & 8175.49 & 108.15 & 0.177 \\
\hline Top 1G & 6199 & 8212.75 & 1042.64 & 0.128 \\
\hline Top 5G & 6199 & 7987.49 & 1247.99 & 1.605 \\
\hline Top 10G & 6199 & 7724.64 & 1958.87 & $2.80 * * *$ \\
\hline Top 25G & 6199 & 7715.35 & 1468.84 & $2.29 * *$ \\
\hline Top 50G & 6199 & 7760.22 & 1072.20 & $1.74 *$ \\
\hline Top 1C & 6199 & 8219.71 & 959.73 & 0.052 \\
\hline Top 5C & 6199 & 8108.70 & 511.03 & 0.702 \\
\hline Top 10C & 6199 & 8023.22 & 655.30 & 0.991 \\
\hline Top $25 \mathrm{C}$ & 6199 & 7921.58 & 660.28 & 1.078 \\
\hline Top 50C & 6199 & 7748.42 & 803.41 & 1.292 \\
\hline \multicolumn{5}{|c|}{ Panel B: Salary and Bonus } \\
\hline Independent Variable & $\mathrm{N}$ & Intercept & Coef./Sig. & \\
\hline UGATT & 6244 & 3049.01 & -195.73 & -0.62 \\
\hline GATT & 6249 & 2770.67 & 177.48 & 0.992 \\
\hline Top $1 \mathrm{U}$ & 6249 & 2857.04 & 505.50 & 1.03 \\
\hline Top $5 \mathrm{U}$ & 6249 & 2803.15 & 661.55 & $2.32 * *$ \\
\hline Top $10 \mathrm{U}$ & 6249 & 2787.23 & 505.06 & $2.157 * *$ \\
\hline Top $25 \mathrm{U}$ & 6249 & 2813.55 & 196.93 & 1.03 \\
\hline Top 50U & 6249 & 2801.68 & 156.38 & 0.883 \\
\hline Top $1 \mathrm{G}$ & 6249 & 2819.86 & 567.25 & $1.89 *$ \\
\hline Top 5G & 6249 & 2792.42 & 428.44 & $1.91 *$ \\
\hline Top 10G & 6249 & 2727.76 & 573.22 & $2.83 * * *$ \\
\hline Top 25G & 6249 & 2757.33 & 336.73 & $1.82^{*}$ \\
\hline Top 50G & 6249 & 2739.87 & 309.59 & $1.74 *$ \\
\hline Top 1C & 6249 & 2811.56 & 543.83 & $1.96 * *$ \\
\hline Top 5C & 6249 & 2796.87 & 338.17 & 1.61 \\
\hline Top 10C & 6249 & 2773.63 & 325.58 & $1.70^{*}$ \\
\hline Top 25C & 6249 & 2708.43 & 359.64 & $2.03 * *$ \\
\hline Top 50C & 6249 & 2736.24 & 232.09 & 1.29 \\
\hline \multicolumn{5}{|l|}{ Panel C: Salary Only } \\
\hline Independent Variable & $\mathrm{N}$ & Intercept & Coef./Sig. & \\
\hline UGATT & 5753 & 772.05 & 70.60 & $2.93 * * *$ \\
\hline GATT & 5758 & 828.44 & 14.07 & 1.03 \\
\hline Top $1 \mathrm{U}$ & 5758 & 839.66 & -93.47 & $2.468 * *$ \\
\hline Top $5 \mathrm{U}$ & 5758 & 835.73 & 7.92 & 0.36 \\
\hline Top $10 \mathrm{U}$ & 5758 & 832.00 & 26.80 & 1.49 \\
\hline Top 25U & 5758 & 833.96 & 8.60 & 0.585 \\
\hline Top 50U & 5783 & 829.44 & 15.57 & 1.15 \\
\hline Top $1 \mathrm{G}$ & 5758 & 829.08 & 79.85 & $3.45^{* * *}$ \\
\hline Top 5G & 5758 & 824.92 & 62.05 & $3.59 * * *$ \\
\hline Top 10G & 5758 & 819.90 & 66.18 & $4.25^{* * *}$ \\
\hline Top 25G & 5758 & 819.68 & 49.16 & $3.45 * * *$ \\
\hline Top 50G & 5758 & 819.62 & 38.74 & $2.84 * * *$ \\
\hline Top 1C & 5758 & 832.84 & 32.94 & 1.54 \\
\hline Top 5C & 5758 & 822.88 & 60.81 & $3.76^{* * * *}$ \\
\hline Top 10C & 5758 & 817.84 & 61.37 & $4.18^{* * *}$ \\
\hline Top 25C & 5758 & 819.50 & 37.36 & $3.75^{* * *}$ \\
\hline Top 50C & 5758 & 806.85 & 50.46 & $3.67 * * *$ \\
\hline
\end{tabular}

This table shows the results of ordinary least squares regressions on compensation components. Panel A reports the results of regressions on total compensation. Panel B reports the results or regressions on salary and bonus. Panel C reports the results of regressions on salary. UGATT and GATT are dummy variables indicating if the CEO has an undergraduate or graduate degree respectively. Top 1, 5, 10, 25 and 50 indicate top schools at each level defined as the schools producing the most CEO's. U, G and C indicate undergraduate, graduate and combined degrees respectively. $* * * * *$ and $*$ indicate significance at the 1,5 and 10 percent levels respectively. 
The coefficient on POWN is significant and negatively related to CEO total compensation. This finding is surprising as logic suggests that individuals owning larger portions of the firm would be able to secure higher salaries for themselves. It may suggest a philanthropy element whereby individuals are willing to reduce the price of their services for a cause they care about. Total assets are positively related to compensation as has been reported in Jalbert Rao and Jalbert, 2002. The coefficients of about 0.030 indicate that for each $\$ 1,000$ increase in assets managed, there is a $\$ 30$ increase in total compensation after controlling for other factors. Interestingly, one year return is negatively related to CEO compensation, but three year returns are positively related to total compensation. This suggests that compensation and performance may misalign in the short term, but firms make adjustments to compensation packages to align performance and compensation in the longer term. Free cash flow and ROA are both positively related to total compensation, again suggesting a positive relationship between total compensation and performance. Industry, Payout Ratio, Sales Growth, Earnings Stability and Price to Book are not significantly related to total compensation.

Table 7 shows the results for regressions on salary. A quick examination indicates substantial differences between the total compensation and salary regressions. First, in the top school regressions, TOP1 is significant and negative for undergraduate, graduate and combined regressions. This suggests that while graduates from Harvard are very successful in reaching top CEO positions, they are somewhat less effective at salary negotiations. The results also show positive significance for the Top 10 combined schools. Years with the company is positive and significant. Interestingly, FOUNDER is negative in the salary regressions. This finding, combined with the findings from Table 6, suggest that founders have a lower salary but earn more from bonuses and stock gains than other CEOs. Gender is marginally significant and positive in the undergraduate regressions indicating that women attract higher salaries than men. Total assets is again strongly significant, but the coefficient size is much smaller and approaches zero. Debt-to-assets are significant and positive, indicating that CEO's of more levered firms earn higher salaries. Free cash flow is also positively and significantly related to salary levels. In contrast to the total compensation regressions, one and three year returns are not significant in explaining salary. It makes sense that salaries are not performance based, but other compensation components are. INDUSTRY, ROA, PAYOUT, SALESGR, EARNSTAB and PRtoBK are not significant in explaining salary.

Table 8 Shows the results of regressions on salary plus bonus. The results show that CEOs who attended the Top5 or Top10 undergraduate schools earned higher salary plus bonus than other CEOs. Those that earned their degree from a top 10 graduate school also earned significantly more than other CEOs. Years as CEO is positively related to salary plus bonus, but YRSCO, FOUNDER, GENDER and POWN are not significantly related to salary plus bonus. Total assets, debt to assets, three year return and ROA are each significantly positively related to salary plus bonus.

The analysis turns to an examination of the extent that the educational background of the CEO predict the performance of the firm. If CEOs from certain educational backgrounds produce superior returns, they should be sought after by the market and compensated appropriately. To explore this issue, we regress the various education indicator variables on the three performance variables, ROA, ROE and ROI. The first regression in Table 9 is specified as follows:

$R O A=\alpha+\beta_{1} U G A T T+\varepsilon$

The results of regressions on ROA, ROE and ROI are presented in Panels A,B, and C respectively. The results indicate that having earned an undergraduate degree is not significant in explaining ROA or ROI, but is positive and significant at the one percent level in explaining ROE. Top10G, TOP25G and TOP50G, and TOP 25C are marginally significant in explaining ROA. In each of these cases, the coefficient is positive. No top school variables are significant in explaining ROE. TOP5U, and TOP $10 \mathrm{U}$ are significant and positive in explaining ROI. TOP1G and TOP1C are negative and significant in explaining ROI. This finding suggests that while Harvard University places many graduates in top CEO positions, Harvard graduates do not provide superior returns. 
Table 6 Regressions on Total Compensation with Control Variables

\begin{tabular}{|c|c|c|c|c|c|}
\hline & UGATT & GATT & UNDERGRAD & GRADUATE & COMBINED \\
\hline Intercept & $-1,223,659$ & -1230191 & -1225758 & -1229914 & -123993 \\
\hline UGATT & $\begin{array}{c}-1656.76 \\
-0.959\end{array}$ & & & & \\
\hline GATT & & $\begin{array}{c}-584.65 \\
-0.607\end{array}$ & & & \\
\hline CEOAGE & $\begin{array}{c}157.47 \\
1.959 * *\end{array}$ & $\begin{array}{l}160.21 \\
1.99 * *\end{array}$ & $\begin{array}{c}158.40 \\
1.97 *\end{array}$ & $\begin{array}{c}159.01 \\
1.981 * *\end{array}$ & $\begin{array}{l}158.30 \\
1.97 * *\end{array}$ \\
\hline YRS CEO & $\begin{array}{c}356.47 \\
4.29 * * *\end{array}$ & $\begin{array}{c}353.36 \\
4.26 * * *\end{array}$ & $\begin{array}{c}350.04 \\
4.21 * * *\end{array}$ & $\begin{array}{c}344.91 \\
4.156 * * *\end{array}$ & $\begin{array}{c}352.69 \\
4.24 * * *\end{array}$ \\
\hline YRS CO & $\begin{array}{l}-66.17 \\
-1.47\end{array}$ & $\begin{array}{l}-69.48 \\
-1.53\end{array}$ & $\begin{array}{l}-65.28 \\
-1.45\end{array}$ & $\begin{array}{c}-60.10 \\
-10.332\end{array}$ & $\begin{array}{l}-65.50 \\
-1.453 \\
\end{array}$ \\
\hline FOUNDER & $\begin{array}{l}5564.80 \\
2.85 * * *\end{array}$ & $\begin{array}{l}5771.20 \\
2.97 * * *\end{array}$ & $\begin{array}{l}5842.15 \\
3.01 * * *\end{array}$ & $\begin{array}{l}5886.86 \\
3.04 * * *\end{array}$ & $\begin{array}{c}5835.37 \\
3.008 * * *\end{array}$ \\
\hline GENDER & $\begin{array}{c}-2988.06 \\
-0.719\end{array}$ & $\begin{array}{c}-3215.87 \\
-0.773\end{array}$ & $\begin{array}{c}-3151.20 \\
-0.757\end{array}$ & $\begin{array}{c}-2816.73 \\
-0.678\end{array}$ & $\begin{array}{c}-3047.90 \\
-0.734\end{array}$ \\
\hline Percent Own & $-430.85 * * *$ & $\begin{array}{c}-442.85 \\
-4.41 * * *\end{array}$ & $\begin{array}{c}-419.36 \\
-4.38 * * * \\
\end{array}$ & $\begin{array}{c}-413.83 \\
-4.325 * * *\end{array}$ & $\begin{array}{c}-419.57 \\
-4.385 * * *\end{array}$ \\
\hline Year & $\begin{array}{c}610.68 \\
3.62 * * *\end{array}$ & $\begin{array}{c}613.36 \\
3.64 * * *\end{array}$ & $\begin{array}{c}610.98 \\
3.628 * * *\end{array}$ & $\begin{array}{c}612.74 \\
3.640 * * *\end{array}$ & $\begin{array}{c}610.08 \\
3.621 * * *\end{array}$ \\
\hline Industry & $\begin{array}{l}35.03 \\
0.942\end{array}$ & $\begin{array}{l}36.82 \\
0.989\end{array}$ & $\begin{array}{l}34.58 \\
0.930\end{array}$ & $\begin{array}{c}36.04 \\
0.97\end{array}$ & $\begin{array}{l}35.22 \\
0.948\end{array}$ \\
\hline Total Assets & $\begin{array}{c}0.029 \\
5.97 * * *\end{array}$ & $\begin{array}{c}0.030 \\
5.993 * * * \\
\end{array}$ & $\begin{array}{c}0.029 \\
5.96 * * *\end{array}$ & $\begin{array}{c}0.029 \\
5.82 * * * \\
\end{array}$ & $\begin{array}{c}0.030 \\
5.98 * * * \\
\end{array}$ \\
\hline Debt to Assets & $\begin{array}{c}2.51 \\
0.101 \\
\end{array}$ & $\begin{array}{c}2.20 \\
0.089 \\
\end{array}$ & $\begin{array}{c}2.11 \\
0.085 \\
\end{array}$ & $\begin{array}{l}0.995 \\
0.04 \\
\end{array}$ & $\begin{array}{c}1.70 \\
0.069\end{array}$ \\
\hline One Yr Return & $\begin{array}{c}-14.51 \\
-2.46^{* * *}\end{array}$ & $\begin{array}{c}-14.39 \\
-2.44 * *\end{array}$ & $\begin{array}{c}-14.48 \\
-2.456 * *\end{array}$ & $\begin{array}{c}-14.44 \\
-2.45^{* *}\end{array}$ & $\begin{array}{c}-14.47 \\
-2.45^{* *}\end{array}$ \\
\hline Three Yr. Return & $\begin{array}{c}94.32 \\
5.73^{* * * *}\end{array}$ & $\begin{array}{c}94.60 \\
5.751^{* * *}\end{array}$ & $\begin{array}{c}94.47 \\
5.744 * * *\end{array}$ & $\begin{array}{c}94.81 \\
5.766^{* * * *}\end{array}$ & $\begin{array}{c}94.41 \\
5.737 * * *\end{array}$ \\
\hline Free Cash Flow & $\begin{array}{l}0.274 \\
1.76^{*}\end{array}$ & $\begin{array}{l}0.272 \\
1.74^{*}\end{array}$ & $\begin{array}{c}0.272 \\
1.740 *\end{array}$ & $\begin{array}{c}0.281 \\
1.797 *\end{array}$ & $\begin{array}{c}0.273 \\
1.748^{*}\end{array}$ \\
\hline ROA & $\begin{array}{l}130.16 \\
2.09 * *\end{array}$ & $\begin{array}{l}129.71 \\
2.08 * *\end{array}$ & $\begin{array}{l}129.64 \\
2.08 * * \\
\end{array}$ & $\begin{array}{l}126.90 \\
2.04 * * \\
\end{array}$ & $\begin{array}{c}130.06 \\
2.087 * *\end{array}$ \\
\hline Payout & $\begin{array}{l}-0.128 \\
-0.178\end{array}$ & $\begin{array}{l}-0.118 \\
-0.165\end{array}$ & $\begin{array}{l}-0.132 \\
-0.184\end{array}$ & $\begin{array}{c}-0.14 \\
-0.195\end{array}$ & $\begin{array}{l}-0.130 \\
-0.182\end{array}$ \\
\hline Sales Growth & $\begin{array}{c}27.19 \\
1.55\end{array}$ & $\begin{array}{c}26.76 \\
1.53\end{array}$ & $\begin{array}{l}27.02 \\
1.543\end{array}$ & $\begin{array}{l}27.53 \\
1.572 \\
\end{array}$ & $\begin{array}{l}27.06 \\
1.545\end{array}$ \\
\hline Earnings Stability & $\begin{array}{c}134.63 \\
0.258 \\
\end{array}$ & $\begin{array}{c}152.08 \\
0.291 \\
\end{array}$ & $\begin{array}{c}143.20 \\
0.274 \\
\end{array}$ & $\begin{array}{c}104.32 \\
0.200 \\
\end{array}$ & $\begin{array}{c}137.78 \\
0.264 \\
\end{array}$ \\
\hline Price to Book & $\begin{array}{l}0.428 \\
0.061\end{array}$ & $\begin{array}{l}0.258 \\
0.037\end{array}$ & $\begin{array}{c}0.22 \\
0.032\end{array}$ & $\begin{array}{l}0.304 \\
0.044\end{array}$ & $\begin{array}{l}0.296 \\
0.042\end{array}$ \\
\hline $\mathbf{N}$ & 3,167 & 3170 & 3170 & 3170 & 3170 \\
\hline F-Statistic & $9.58 * * *$ & $9.86^{* * *}$ & 9.841 *** & $9.97 * * *$ & $9.83^{* * *}$ \\
\hline R2 & 0.056 & 0.056 & 0.056 & 0.057 & 0.056 \\
\hline Adj. R2 & 0.050 & 0.050 & 0.050 & 0.051 & 0.050 \\
\hline Top 1 & & & $\begin{array}{c}1189.66 \\
0.418 \\
\end{array}$ & $\begin{array}{c}706.37 \\
0.446 \\
\end{array}$ & $\begin{array}{c}901.36 \\
0.617 \\
\end{array}$ \\
\hline Top 5 & & & $\begin{array}{c}1273.96 \\
0.846\end{array}$ & $\begin{array}{c}1169.69 \\
1.011 \\
\end{array}$ & $\begin{array}{c}314.90 \\
0.287\end{array}$ \\
\hline Top 10 & & & $\begin{array}{c}419.68 \\
0.341\end{array}$ & $\begin{array}{c}1673.95 \\
1.582\end{array}$ & $\begin{array}{l}-7.296 \\
-0.007\end{array}$ \\
\hline Top 25 & & & $\begin{array}{c}238.49 \\
0.235\end{array}$ & $\begin{array}{c}998.08 \\
1.03\end{array}$ & $\begin{array}{c}-238.73 \\
-0.256\end{array}$ \\
\hline Top 50 & & & $\begin{array}{l}-651.02 \\
-0.701 \\
\end{array}$ & $\begin{array}{c}944.19 \\
1.01 \\
\end{array}$ & $\begin{array}{c}1213.99 \\
1.286 \\
\end{array}$ \\
\hline
\end{tabular}

This table shows regressions on Total Compensation. A degree or top school indicator is included in each regression, GATT, UGATT and Top1, Top5, Top 10, Top 25, and Top 50 as identified from Table 2. In addition, a series of control variables are included in each regression. The coefficients and significance of control variables are presented for the regressions on the Top 10, undergraduate graduate and combined regressions only. The coefficients for the remaining top school indicators, without control variable statistics are also presented. $* * *, * *$ and $*$ indicate significance at the 1,5 and 10 percent levels respectively. 
Table 7 Regressions on Salary with Control Variables

\begin{tabular}{|c|c|c|c|c|c|}
\hline & UGATT & GATT & UNDERGRAD & GRADUATE & COMBINED \\
\hline Intercept & -73239 & -73455 & -73297 & -73396 & -73764.7 \\
\hline UGATT & $\begin{array}{l}17.86 \\
0.499 \\
\end{array}$ & & & & \\
\hline GATT & & $\begin{array}{c}-17.551 \\
-0.874\end{array}$ & & & \\
\hline CEOAGE & $\begin{array}{c}8.62 \\
5.193 * * *\end{array}$ & $\begin{array}{c}8.654 \\
5.217^{* * * *}\end{array}$ & $\begin{array}{c}8.61 \\
5.193^{*} * * \\
\end{array}$ & $\begin{array}{c}8.633 \\
5.209 * * *\end{array}$ & $\begin{array}{c}8.648 \\
5.219 * * *\end{array}$ \\
\hline YRS CO & $\begin{array}{c}1.946 \\
2.077^{* *}\end{array}$ & $\begin{array}{c}1.824 \\
1.928 *\end{array}$ & $\begin{array}{c}1.943 \\
2.075 * *\end{array}$ & $\begin{array}{c}2.046 \\
2.180 * *\end{array}$ & $\begin{array}{c}2.038 \\
2.175 * *\end{array}$ \\
\hline FOUNDER & $\begin{array}{c}-113.53 \\
-2.791 * * *\end{array}$ & $\begin{array}{c}-117.22 \\
-2.899 * * *\end{array}$ & $\begin{array}{c}-115.33 \\
-2.855^{* * *}\end{array}$ & $\begin{array}{c}-114.59 \\
-2.838 * * *\end{array}$ & $\begin{array}{c}-115.11 \\
-2.852 * * *\end{array}$ \\
\hline GENDER & $\begin{array}{l}144.97 \\
1.688^{*}\end{array}$ & $\begin{array}{c}140.73 \\
1.637 \\
\end{array}$ & $\begin{array}{l}143.95 \\
1.673 * \\
\end{array}$ & $\begin{array}{l}150.37 \\
1.751 * \\
\end{array}$ & $\begin{array}{c}140.33 \\
1.635 \\
\end{array}$ \\
\hline Percent Own & $\begin{array}{c}-9.6 \\
-5.074 * * * \\
\end{array}$ & $\begin{array}{c}-9.811 \\
-5.203 * * * \\
\end{array}$ & $\begin{array}{c}-9.686 \\
-5.149 * * * \\
\end{array}$ & $\begin{array}{c}-9.552 \\
-5.075^{* * *} \\
\end{array}$ & $\begin{array}{c}-9.588 \\
-5.099 * * * \\
\end{array}$ \\
\hline Year & $\begin{array}{c}36.76 \\
10.44^{* * *}\end{array}$ & $\begin{array}{c}36.877 \\
10.489 * * *\end{array}$ & $\begin{array}{c}36.79 \\
10.46^{* * * *}\end{array}$ & $\begin{array}{c}36.835 \\
10.476 * * *\end{array}$ & $\begin{array}{c}37.02 \\
10.526^{* * * *}\end{array}$ \\
\hline Industry & $\begin{array}{c}-3.92 \\
-5.05^{* * * *}\end{array}$ & $\begin{array}{c}-3.869 \\
-4.977 * * *\end{array}$ & $\begin{array}{c}-3.927 \\
-5.057 * * *\end{array}$ & $\begin{array}{c}-3.901 \\
-5.032 * * *\end{array}$ & $\begin{array}{c}-3.892 \\
-5.022 * * *\end{array}$ \\
\hline Total Assets & $\begin{array}{c}0.000 \\
4.571^{* * *}\end{array}$ & $\begin{array}{c}0.000 \\
4.590^{* * *}\end{array}$ & $\begin{array}{c}0.000 \\
4.551^{* * * *}\end{array}$ & $\begin{array}{c}0.000 \\
4.413^{* * * *}\end{array}$ & $\begin{array}{c}0.000 \\
4.502 * * *\end{array}$ \\
\hline Debt to Assets & $\begin{array}{c}1.055 \\
2.038^{* *} * \\
\end{array}$ & $\begin{array}{c}1.084 \\
2.097^{*} * \\
\end{array}$ & $\begin{array}{c}1.075 \\
2.078 * *\end{array}$ & $\begin{array}{c}1.054 \\
2.040^{* *}\end{array}$ & $\begin{array}{c}1.100 \\
2.129 * *\end{array}$ \\
\hline One Yr Return & $\begin{array}{l}-0.185 \\
-1.498 \\
\end{array}$ & $\begin{array}{r}-0.182 \\
-1.487\end{array}$ & $\begin{array}{r}-0.185 \\
-1.499\end{array}$ & $\begin{array}{r}-0.184 \\
-1.493 \\
\end{array}$ & $\begin{array}{r}-0.190 \\
-1.546 \\
\end{array}$ \\
\hline Three Yr. Return & $\begin{array}{l}-0.410 \\
-1.197 \\
\end{array}$ & $\begin{array}{l}-0.409 \\
-1.190 \\
\end{array}$ & $\begin{array}{l}-0.413 \\
-1.206 \\
\end{array}$ & $\begin{array}{c}-0.40 \\
-1.188 \\
\end{array}$ & $\begin{array}{l}-0.391 \\
-1.144 \\
\end{array}$ \\
\hline Free Cash Flow & $\begin{array}{c}0.010 \\
2.992^{* * *} *\end{array}$ & $\begin{array}{c}0.010 \\
2.988^{* * * *}\end{array}$ & $\begin{array}{c}0.010 \\
2.987^{* * * *}\end{array}$ & $\begin{array}{c}0.010 \\
3.039 * * *\end{array}$ & $\begin{array}{c}0.010 \\
2.985 * * *\end{array}$ \\
\hline ROA & $\begin{array}{l}2.030 \\
1.619 \\
\end{array}$ & $\begin{array}{c}2.03 \\
1.620 \\
\end{array}$ & $\begin{array}{l}2.038 \\
1.626 \\
\end{array}$ & $\begin{array}{l}1.987 \\
1.586 \\
\end{array}$ & $\begin{array}{l}2.011 \\
1.605 \\
\end{array}$ \\
\hline Sales Growth & $\begin{array}{l}-0.469 \\
-1.281 \\
\end{array}$ & $\begin{array}{l}-0.477 \\
-1.302 \\
\end{array}$ & $\begin{array}{l}-0.468 \\
-1.280 \\
\end{array}$ & $\begin{array}{l}-0.458 \\
-1.251 \\
\end{array}$ & $\begin{array}{l}-0.468 \\
-1.280 \\
\end{array}$ \\
\hline Earnings Stability & $\begin{array}{l}-9.728 \\
-0.906 \\
\end{array}$ & $\begin{array}{l}-9.211 \\
-0.857 \\
\end{array}$ & $\begin{array}{l}-9.554 \\
-0.890 \\
\end{array}$ & $\begin{array}{c}-10.348 \\
-0.963\end{array}$ & $\begin{array}{l}-9.799 \\
-0.913\end{array}$ \\
\hline Price to Book & $\begin{array}{l}-0.108 \\
-0.739 \\
\end{array}$ & $\begin{array}{l}-0.108 \\
-0.741 \\
\end{array}$ & $\begin{array}{l}-0.108 \\
-0.742 \\
\end{array}$ & $\begin{array}{r}-0.107 \\
0.734 \\
\end{array}$ & $\begin{array}{l}-0.116 \\
-0.794 \\
\end{array}$ \\
\hline $\mathbf{N}$ & 3185 & 3188 & 3188 & 3188 & 3188 \\
\hline F-Statistic & $18.67 * * *$ & $18.72 * * *$ & $18.677 * * *$ & $18.813 * * *$ & $18.914 * * *$ \\
\hline $\mathbf{R 2}$ & 0.101 & 0.101 & 0.101 & 0.101 & 0.102 \\
\hline Adj. R2 & 0.095 & 0.096 & 0.095 & 0.0969 & 0.096 \\
\hline Top 1 & & & $\begin{array}{c}-123.91 \\
-2.107 * *\end{array}$ & $\begin{array}{c}90.695 \\
2.742 * * *\end{array}$ & $\begin{array}{l}51.263 \\
1.681 *\end{array}$ \\
\hline Top 5 & & & $\begin{array}{l}-9.919 \\
-0.316\end{array}$ & $\begin{array}{c}38.224 \\
1.581\end{array}$ & $\begin{array}{l}36.67 \\
1.603\end{array}$ \\
\hline Top 10 & & & $\begin{array}{l}6.617 \\
0.257\end{array}$ & $\begin{array}{c}34.157 \\
1.544\end{array}$ & $\begin{array}{c}42.343 \\
2.029 * *\end{array}$ \\
\hline Top 25 & & & $\begin{array}{l}-2.270 \\
-0.107\end{array}$ & $\begin{array}{l}0.962 \\
0.047\end{array}$ & $\begin{array}{l}-1.059 \\
-0.055\end{array}$ \\
\hline Top 50 & & & $\begin{array}{c}-15.631 \\
-0.807 \\
\end{array}$ & $\begin{array}{l}-2.541 \\
-0.130 \\
\end{array}$ & $\begin{array}{c}12.963 \\
0.658 \\
\end{array}$ \\
\hline
\end{tabular}

This table shows regressions on Salary. A degree or top school indicator is included in each regression, GATT, UGATT and Top 1, Top5, Top 10, Top 25, and Top 50 as identified from Table 2. In addition, a series of control variables are included in each regression. The coefficients and significance of control variables are presented for the regressions on the Top 10, undergraduate graduate and combined regressions only. The coefficients for the remaining top school indicators, without control variable statistics are also presented. $* * * * *$ and $*$ indicate significance at the 1,5 and 10 percent levels respectively. 
Table 8 Regressions on Salary plus Bonus with Control Variables

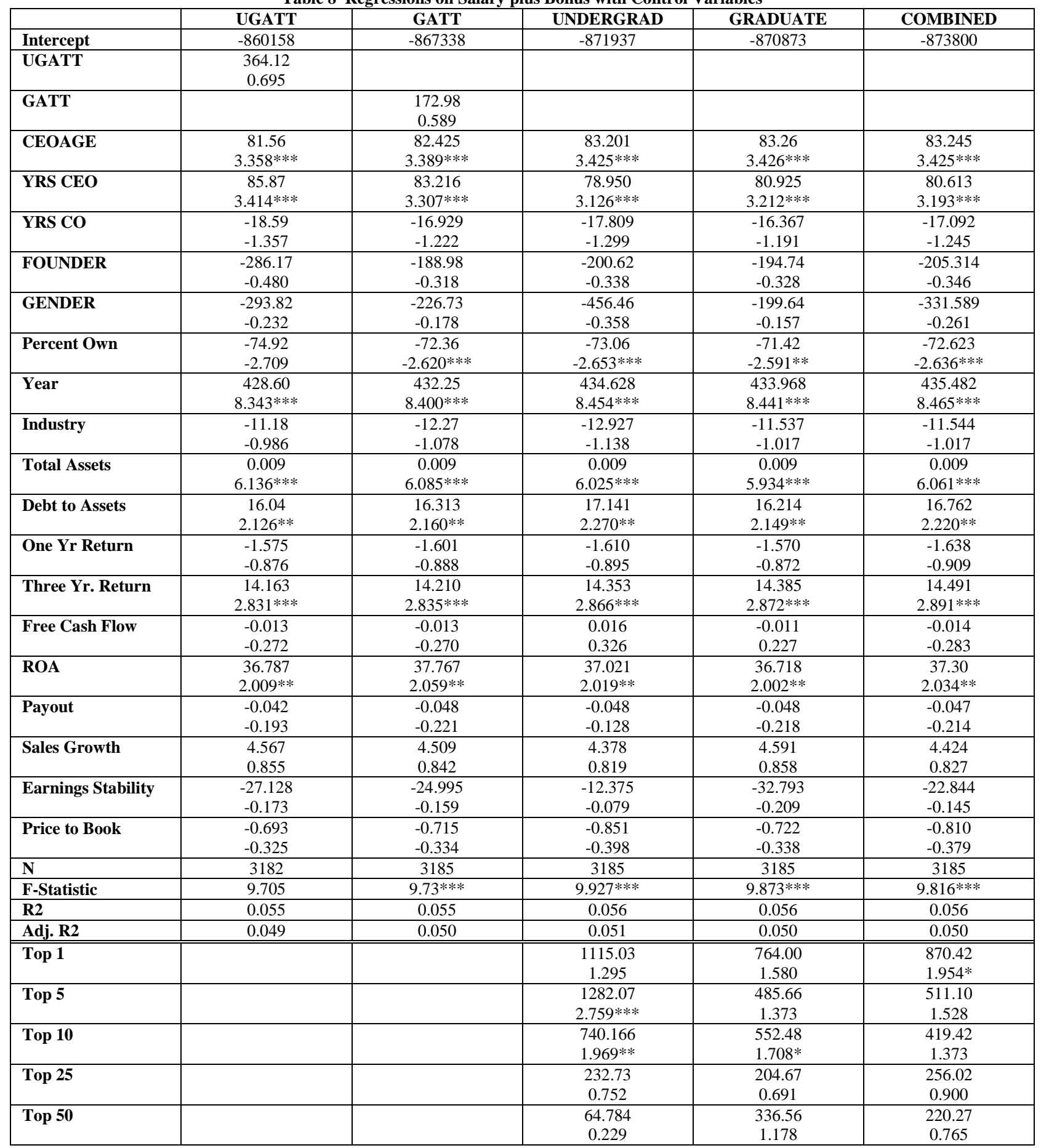

This table shows regressions on Salary plus Bonus. A degree or top school indicator is included in each regression, GATT, UGATT and Top1, Top5, Top 10, Top 25, and Top 50 as identified from Table 2. In addition, a series of control variables are included in each regression. The coefficients and significance of control variables are presented for the regressions on the Top 10, undergraduate graduate and combined regressions only. The coefficients for the remaining top school indicators, without control variable statistics are also presented. $* * * * *$ and $*$ indicate significance at the 1,5 and 10 percent levels respectively. 
Table 9: Regressions on Return Measures

\begin{tabular}{|c|c|c|c|c|}
\hline \multicolumn{5}{|c|}{ Panel A: Return on Assets } \\
\hline Independent Variable & $\mathrm{N}$ & Intercept & Coefficient & T-Statistic \\
\hline UGATT & 5733 & 3.153 & 1.038 & 1.517 \\
\hline GATT & 5738 & 4.234 & -0.230 & -0.593 \\
\hline Top $1 \mathrm{U}$ & 5738 & 4.138 & -1.220 & -1.122 \\
\hline Top 5U & 5738 & 4.078 & 0.199 & 0.321 \\
\hline Top 10U & 5738 & 3.962 & 0.812 & 1.592 \\
\hline Top 25U & 5738 & 4.138 & -0.127 & -0.306 \\
\hline Top 50U & 5738 & 4.190 & -0.197 & -0.514 \\
\hline Top $1 \mathrm{G}$ & 5738 & 4.175 & -0.814 & 1.234 \\
\hline Top 5G & 5738 & 4.003 & 0.515 & 1.053 \\
\hline Top 10G & 5738 & 3.900 & 0.786 & $1.792 *$ \\
\hline Top 25G & 5738 & 3.869 & 0.661 & $1.649^{*}$ \\
\hline Top 50G & 5738 & 3.780 & 0.739 & $1.917^{*}$ \\
\hline Top 1C & 5738 & 4.192 & -0.825 & -1.366 \\
\hline Top 5C & 5738 & 4.073 & 0.120 & 0.261 \\
\hline Top 10C & 5738 & 3.897 & 0.664 & 1.601 \\
\hline Top 25C & 5738 & 3.732 & 0.806 & $2.103 * *$ \\
\hline Top 50C & 5738 & 3.763 & 0.568 & 1.460 \\
\hline \multicolumn{5}{|c|}{ Panel B: Return on Equity } \\
\hline Independent Variable & $\mathrm{N}$ & Intercept & Coef./Sig. & \\
\hline UGATT & 5570 & -6.587 & 21.437 & $2.910 * * *$ \\
\hline GATT & 5575 & 10.355 & 4.538 & 1.089 \\
\hline Top $1 \mathrm{U}$ & 5575 & 13.116 & -3.076 & -0.266 \\
\hline Top 5U & 5575 & 13.020 & -0.029 & -0.004 \\
\hline Top $10 \mathrm{U}$ & 5575 & 12.830 & 1.115 & 0.203 \\
\hline Top 25U & 5575 & 13.065 & -0.161 & -0.036 \\
\hline Top 50U & 5575 & 11.939 & 2.345 & 0.569 \\
\hline Top $1 \mathrm{G}$ & 5575 & 13.052 & -0.386 & -0.054 \\
\hline Top 5G & 5575 & 12.896 & 0.645 & 0.123 \\
\hline Top 10G & 5575 & 11.935 & 4.239 & 0.900 \\
\hline Top 25G & 5575 & 11.658 & 3.875 & 0.901 \\
\hline Top 50G & 5575 & 11.217 & 4.150 & 1.002 \\
\hline Top 1C & 5575 & 13.102 & -0.764 & -0.117 \\
\hline Top 5C & 5575 & 12.932 & 0.377 & 0.076 \\
\hline Top 10C & 5575 & 12.024 & 3.250 & 0.729 \\
\hline Top 25C & 5575 & 11.513 & 3.295 & 0.799 \\
\hline Top 50C & 5575 & 10.528 & 4.200 & 1.005 \\
\hline \multicolumn{5}{|c|}{ Panel C: Return on Investment } \\
\hline Independent Variable & $\mathrm{N}$ & Intercept & Coef./Sig. & \\
\hline UGATT & 5672 & 6.509 & 2.052 & 1.243 \\
\hline GATT & 5677 & 8.770 & $\frac{2.032}{-0.664}$ & $\begin{array}{l}-0.709 \\
-0.709\end{array}$ \\
\hline Top $1 \mathrm{U}$ & 5677 & 8.402 & -0.680 & -0.256 \\
\hline Top 5U & 5677 & 8.097 & 2.702 & $1.797^{*}$ \\
\hline Top 10U & 5677 & 7.923 & 2.732 & $2.214 * *$ \\
\hline Top 25U & 5677 & 8.648 & -0.878 & -0.877 \\
\hline Top 50U & 5677 & 8.342 & 0.120 & 0.129 \\
\hline Top 1G & 5677 & 8.779 & -4.329 & $-2.718 * * *$ \\
\hline Top 5G & 5677 & 8.676 & -1.587 & -1.336 \\
\hline Top 10G & 5677 & 8.545 & -0.288 & -0.272 \\
\hline Top 25G & 5677 & 8.412 & $\begin{array}{l}-0.080 \\
-0.089\end{array}$ & -0.092 \\
\hline Top 50G & 5677 & 8.325 & 0.128 & 0.138 \\
\hline Top 1C & 5677 & 8.779 & -3.578 & $-2.443^{* *} *$ \\
\hline Top 5C & 5677 & 8.704 & -1.448 & -1.308 \\
\hline Top 10C & 5677 & 8.487 & -0.348 & -0.348 \\
\hline Top 25C & 5677 & 8.341 & 0.087 & 0.094 \\
\hline Top 50C & 5677 & 8.451 & -0.119 & -0.127 \\
\hline
\end{tabular}

This table shows the results of ordinary least squares regressions on three measures of return. Panel A reports the results of regressions on Return on Assets. Panel B reports the results or regressions on Return on Equity. Panel C reports the results of regressions on Return on Investment. UGATT and GATT are dummy variables indicating if the CEO has an undergraduate or graduate degree respectively. Top 1, 5, 10, 25 and 50 indicate top schools at each level defined as the schools producing the most CEO's. U, G and C indicate undergraduate, graduate and combined degrees respectively. $* * * * *$ and $*$ indicate significance at the 1,5 and 10 percent levels respectively. 
Next, a series of control variables are included in each of the performance regressions. The analysis regresses one educational variable, and a series of control variables on one of the three performance measures. The regression presented in the first column of Table 10 is specified as follows:

$$
\begin{array}{rl}
\text { ROA }=\alpha+\beta_{1} U & G A T T+\beta_{2} \text { CEOAGE }+\beta_{3} \text { YRSCEO }+\beta_{4} \text { YRSCO }+\beta_{5} \text { FOUNDER }+\beta_{6} \text { GENDER }+\beta_{7} \text { POWN } \\
& +\beta_{8} \text { YEAR }+\beta_{9} \text { INDUSTRY }+\beta_{10} \text { ASSETS }+\beta_{11} \text { DBTtoASTS }+\beta_{12} \text { ONEyrRET } \\
& +\beta_{13} \text { THyrRET }+\beta_{14} \text { Free CaSh Flow }+\beta_{15} \text { PAYOUT }+\beta_{16} \text { SALESGR }+\beta_{17} \text { EARNSTAB } \\
& +\beta_{18} \text { PtoB }+\varepsilon
\end{array}
$$

Tables 10 and 11 present results for regressions on ROA and ROI respectively. Regressions on ROE are not presented because of limited evidence of significance in the regressions in Table 9. In the same manner as Tables 6-8, columns in the tables present the results when various educational variables are substituted into Equation 4. The first two columns include the degree earned variables UGATT and GATT. Columns three through five provide an analysis for top undergraduate, graduate and combined schools respectively. The control variable estimates are presented only for the TOP 10 education variable to conserve space. Coefficients for the education variables obtained from separate regressions are presented at the bottom of the table.

The results of regressions on ROA are presented in Table 10. The results show that UGATT and GATT are not significant in explaining ROA. Top $25 \mathrm{U}$ is negative and marginally significant and Top10G is positive and marginally significant in explaining ROA. CEO age is positively related to ROA, however; the number of years as CEO is negatively related to ROA. This finding is consistent with arguments that seasoned CEOs are less aggressive than new CEOs, taking less risks and earning lower returns. POWN is positively related to ROA, suggesting that higher levels of ownership motivate managers to perform better. Total assets are negatively related to ROA. This size effect confirms the findings of many other studies that find small firms perform better than large firms. One-year return is not significant in explaining ROA, but three year returns has positive explanatory power over ROA. Both risk measures, Earnings Stability and Price-to-Book are significant in explaining ROA. FOUNDER is not significant in explaining ROA. This finding is a reversal of Jalbert, Rao and Jalbert (2002) who found that founders earn higher returns than non founders. GENDER, Free cash flow, dividend payouts, and sales growth are not significant in explaining ROA.

Table 11 presents results of regressions on Return on Investment (ROI). The most striking finding from this table is that the top graduate and combined university (Harvard) is significantly negative in explaining ROI. The results are significant at the one percent level. The results also indicate that top 25 and top 50 undergraduate school graduates produce lower ROI than other schools. Interestingly, in contrast to the ROA regressions, total assets are not significant in explaining Return on Investment.

\section{SECTION 6: CONCLUDING COMMENTS}

This paper examines compensation and performance of CEOs from the largest U.S. firms. Data from the Forbes Magazine Compensation list was merged with Compustat data for the time period of 1997-2006. This paper is an extension of Jalbert, Rao and Jalbert (2002). Jalbert, Rao and Jalbert examined data from 1987-1996, so this paper represents ten year forward move in time.

Universities are ranked based on the number of CEOs they place in top CEO positions. Rankings are provided for undergraduate, graduate and combined degrees. The results show that over the past ten years, Harvard University has taken over the number one undergraduate provider spot.

Harvard is now the leader in all three categories, undergraduate, graduate and combined degrees. Harvard accounts for 11.5 percent of all CEO's and 12.5 of CEOs that have a degree. The top fifty schools provide an education to some 73.3 percent of all CEOs. Universities are also ranked based on the total compensation their graduates earn as a CEO. The results show significant disparity between the number of graduates placed as a CEO and the compensation earned as CEO. Graduates from City University New York Queens and City University New York City earn the highest total compensation as CEO. 
Table 10 Regressions on Return on Assets with Control Variables

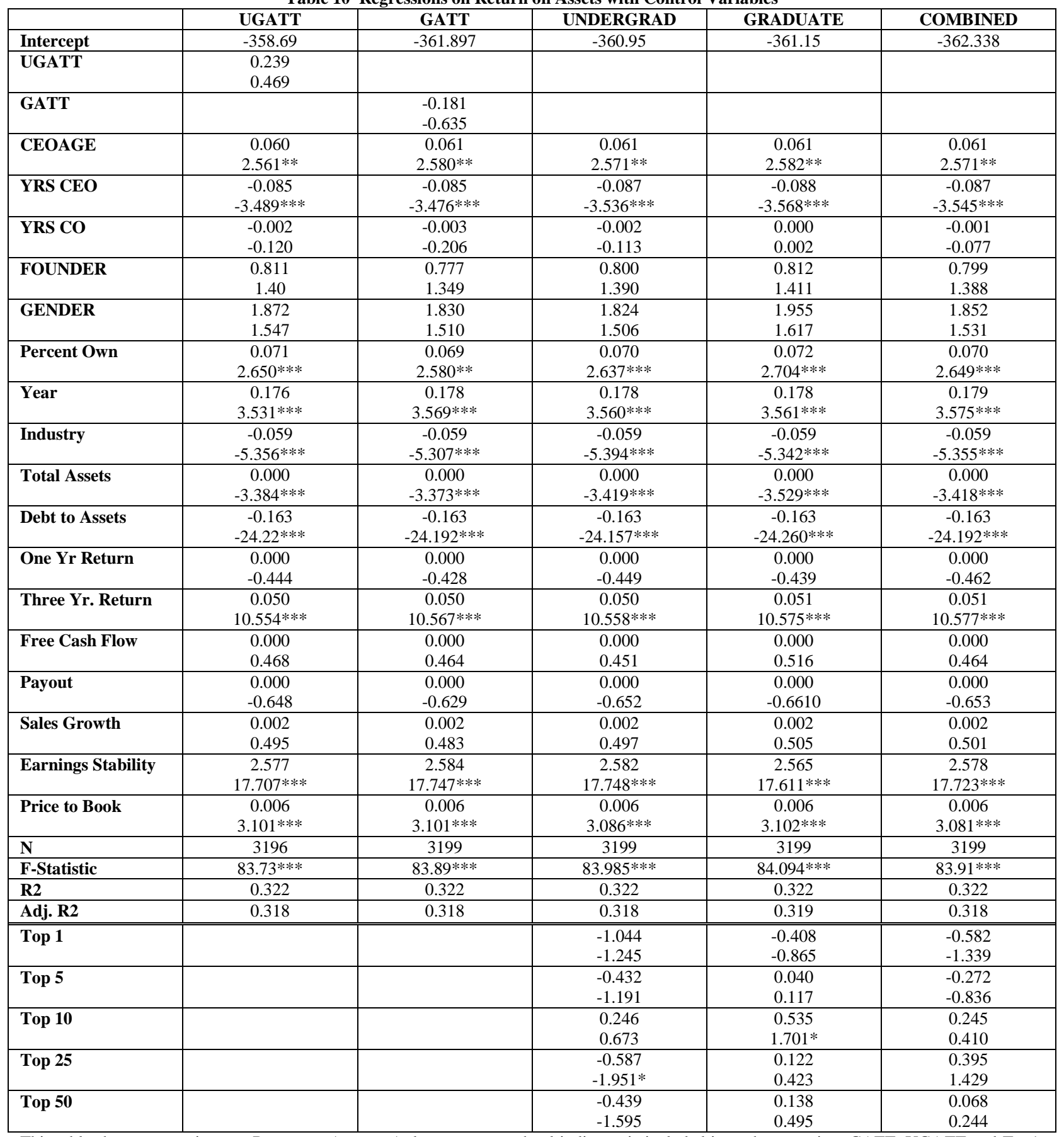

This table shows regressions on Return on Assets. A degree or top school indicator is included in each regression, GATT, UGATT and Top1, Top5, Top 10, Top 25, and Top 50 as identified from Table 2. In addition, a series of control variables are included in each regression. The coefficients and significance of control variables are presented for the regressions on the Top 10, undergraduate graduate and combined regressions only. The coefficients for the remaining top school indicators, without control variable statistics are also presented. $* * * * *$ and $*$ indicate significance at the 1,5 and 10 percent levels respectively. 
Table 11 Regressions on Return on Investment with Control Variables

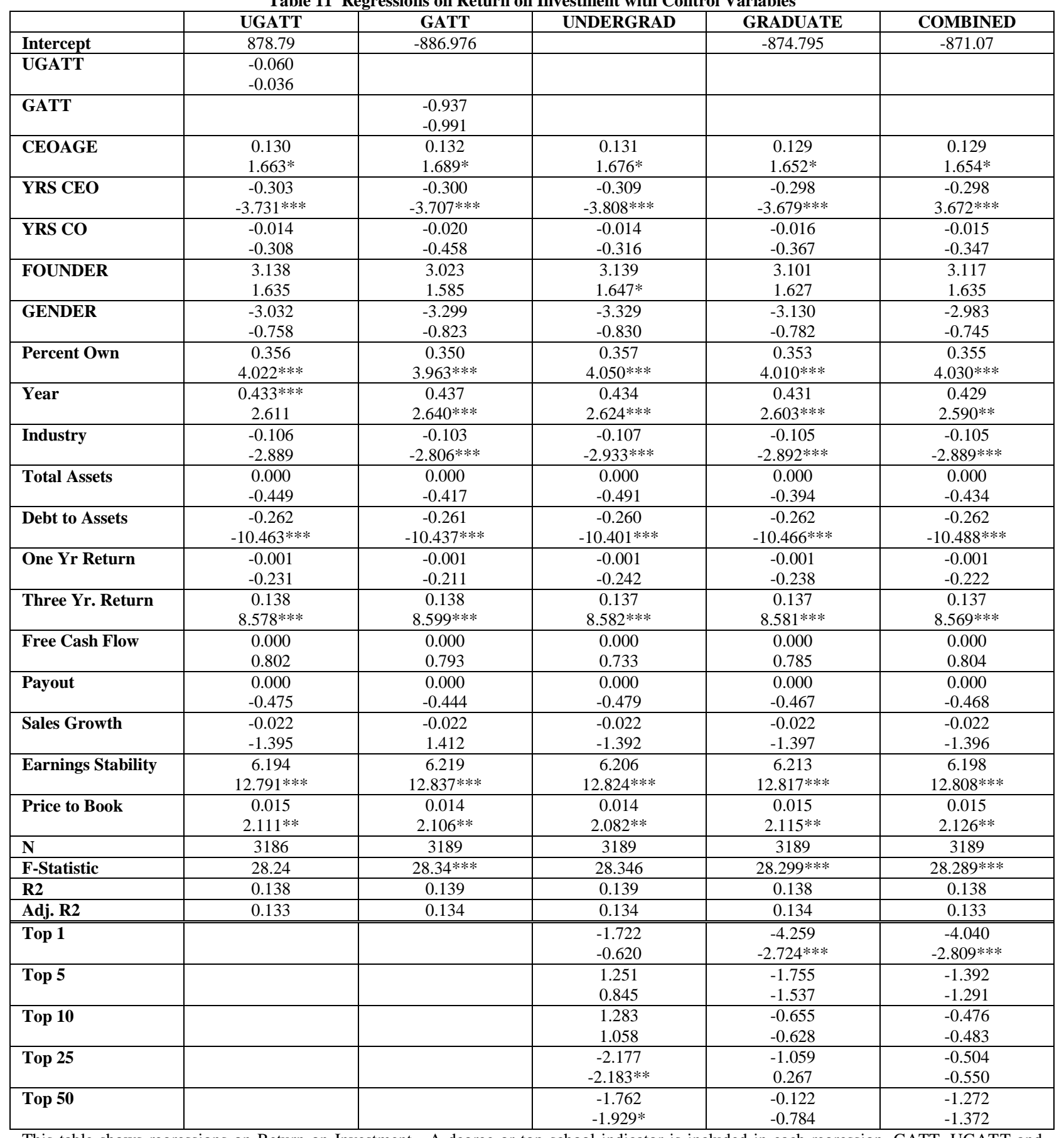

This table shows regressions on Return on Investment. A degree or top school indicator is included in each regression, GATT, UGATT and Top1, Top5, Top 10, Top 25, and Top 50 as identified from Table 2. In addition, a series of control variables are included in each regression. The coefficients and significance of control variables are presented for the regressions on the Top 10, undergraduate graduate and combined regressions only. The coefficients for the remaining top school indicators, without control variable statistics are also presented. ***,** and * indicate significance at the 1,5 and 10 percent levels respectively.

Regressions on compensation and performance variables were completed. Evidence from these regressions was mixed concerning the impact of educational background on CEO compensation as well as on CEO performance. Perhaps the most interesting finding in the study is that while Harvard University places many 
graduates in CEO positions, by some measures, Harvard graduates produce lower returns for their investors.

While many findings in this paper are consistent with those of Jalbert, Rao and Jalbert (2002) there are several notable exceptions. University rankings show significant changes over the past ten years. For example, University of Wisconsin improved from 13th to 4th place in placing CEOs over the past ten years. Compensation rankings also show significant differences. For example, Long Island University while unranked in Jalbert, Rao and Jalbert, 2002, ranks 5th in the current study. Dickinson and Fairleigh Dickinson, while previously ranked very high, dropped out of the rankings in this study. While elements of total compensation compression, whereby CEOs that have been with the company longer earn less, were evident in the earlier study, no relationship is identified here. When examining the salary measure of compensation, years with the company is positive and significant in this study.

A great deal of research remains to be done on the role that education plays on compensation and performance of CEOs. This study does not address how the specific degree earned impacts compensation and performance. If CEOs with different degrees perform differently, and the mix of degrees offered by universities differs, the results of this study could be biased. In addition, schools are ranked here based on popularity. Further insights might be gained by examining other measures of University quality such as average SAT or GMAT scores.

\section{AUTHOR INFORMATION}

Terrance Jalbert is Professor of Finance at the University of Hawaii at Hilo. His research appears in Journals that include, International Journal of Finance, Financial Services Review, Journal of Applied Business Research, International Journal of Business and Finance Research and Journal of Accounting Education. He can be reached at University of Hawaii at Hilo, College of Business and Economics, 200 West Kawili St., Hilo, HI 96720. Email: jalbert@hawaii.edu

Kim Furumo is Assistant Professor of Management Information Systems. Her research appears in journals that include Communications of the ACM, the Journal of Computer Information Systems, the Interdisciplinary Journal of Information, Knowledge, and Management, the Journal of Information Technology Cases and Applications, the Journal of Information, Information Technology, and Organizations, and the International Journal of Electronic Marketing and Retailing She can be reached at University of Hawaii at Hilo, College of Business and Economics, 200 West Kawili St., Hilo, HI 96720. Email: furumo@ hawaii.edu.

Mercedes Jalbert is Managing Editor for the Institute for Business and Finance Research. Her research appears in journals such as Accounting and Taxation, Tax Notes, Journal of Emerging Markets, International Journal of Management and Marketing Research and Financial Services Review. She can be reached at P.O. Box 4908, Hilo, HI 96720 Email: admin@theIBFR.com.

\section{REFERENCES}

1. Adams, Renee, Heitor Almeida and Daniel Ferreira (2009) "Understanding the Relationship Between Founder-CEOs and Firm Performance," Journal of Empirical Finance, vol. 16, p. 136-150.

2. Aggarwal, R. and A. Samwisk. 1999. The Other Side of the Trade-Off: The Impact of Risk on Executive Compensation. Journal of Political Economy. v. 107, 65-105.

3. Baker, G. and B. Hall. 2002. CEO Incentives and Firm Size. NBER working Paper. No. 6868.

4. Baker, M. G. Jensen and K.J. Murphy. 1988. Compensation and Incentives: Practice vs. Theory. Journal of Finance. v. 43(3) 593-616.

5. Bantel, K.A. and S.E. Jackson (1989) "Top Management and Innovations in Banking: Does the Composition of the Top Team Make a Difference?" Strategic Management Journal vol. 10, p. 107-124.

6. Banz, R. 1981. The Relationship Between Return and Market Value of Common Stocks. Journal of Financial Economics. v. 9(March), 3-18.

7. Barker, V.L. and G.C. Mueller (2002) “CEO Characteristics and Firm R\&D Spending,” Management Science, vol. 48(6, June) p. 782-801. 
8. Barragato, C. 2002. Linking For-Profit and Nonprofit Executive Compensation: Salary Composition and Incentive Structures in the U.S. Hospitality Industry. International Journal of Voluntary and Nonprofit Organizations. V. 13 (3, September) 301-311.

9. Barro, J.R. and R.J. Barro. 1990. Pay, Performance and Turnover of Bank CEOs. Journal of Labor Economics. v. 8, 448-481.

10. Beaty, R.P. and E.J. Zajac (1994) "Managerial Incentives, Monitoring, and Risk Bearing: A Study of Executive Compensation, Ownership, and Board Structure in Initial Public Offerings," Administrative Science Quarterly, vol. 39(2, June), p. 313-335

11. Bebchuk, L.A., M. Cremers and U. Peyer (2009) "The CEO Pay Slice," Working Paper

12. Berry, T., J. Bizjak, M. Lemmon, and L. Naveen. 2000. CEO Turnover and Firm Diversification. v. 22 (March). Social Science Research Network Electronic Library. http://ssrn.com/219934, 9.

13. Bhattacharyya, Nalinaksha, Amin Mawani and Cameron K.J. Moril (2008a) "Dividend Payout and Executive Compensation: Theory and Canadian Evidence," Managerial Finance, vol. 34(8), p. 585-601.

14. Bhattacharyya, Nalinaksha, Amin Mawani and Cameron K.J. Moril (2008b) 'Dividend Payout and Executive Compensation: Theory and Evidence," Accounting and Finance, vol. 48(4, December), p. 521541.

15. Brick, I., O. Palmon, and J. Wald. 2003. CEO Compensation, Director Compensation, and Firm Performance: Evidence of Cronyism. Working Paper.

16. Broussard, John Paul, Sheree A. Buchenroth and Eugene A. Pilotte (2004) "CEO Incentives, Cash Flow and Investment," Financial Management vol. 33, p. 51-70

17. Carpenter, M.A., M.A. Geletkanycz, and W. G. Sanders (2004) “Upper Echelons Research Revisited: Antecedents, Elements and Consequences of Top Management Team Composition," Journal of Management, vol. 30(6) p. 749-778.

18. Chevalier J. and G. Ellison (1999) “Are Some Mutual Fund Mangers Better than Others? Cross Sectional Patterns in Behavior and Performance," Journal of Finance, vol. 54, p. 875-899.

19. Collier, B. and M.J. Wilson (1994) "Fortune 1,000 Chief Financial Officers on Business School Education," Financial Practice and Education, Fall/Winter, p. 47-58.

20. Cooper, M.J. H. Gulen and P.R. Rau (2009) "Performance for Pay? The Relationship between CEO Incentive Compensation and Future Stock Price Performance, Working Paper

21. Datta K. and J. Guthrie. 1994. Executive Succession: Organizational Antecedents of CEO Characteristics. Strategic Management Journal. v. 15(7), 569-77.

22. Dechow, P.M. (2006) "Asymmetric Sensitivity of CEO Cash Compensation to Stock Returns: A Discussion," Journal of Accounting and Economics, vol. 42(1-2), p. 193-202.

23. DeAngelo, H. and R. Masulis. 1980. Optimal Capital Structure Under Corporate and Personal Taxation. The Journal of Financial Economics. March, 3-30.

24. Dollinger, M.J. (1984) "Environmental Boundry Spanning and Information Processing Effects on Organizational Performance," Academy of Management Journal, vol. 27, p. 351-368

25. Easterbrook, F. 1984. Two Agency-Cost Explanations of Dividends. American Economic Review. v. 74 (September), 650-59.

26. Fahlengrach, R. 2004. Founder-CEOs And Stock Market Performance. Job Market Paper

27. Fahlengrach, R. 2005. Founder-CEOs and Stock Market Performance. The Ohio State University. Working Paper. July 27, 2005 version, 1-61

28. Fahlenbrach, R. (2009) "Founder CEOs and Stock Market Performance," Journal of Financial and Quantitative Analysis, vol. 44, p. 439-466.

29. Fama, E.G. 1980. Agency Problems and the Theory of the Firm. Journal of Political Economy. 88 (April) 288-307.

30. Fama, E. and H. Babiak. 1968. Dividend Policy: An Empirical Analysis. Journal of the American Statistical Association. v. 63 (Dec.) p. 1132-61.

31. Fama, E. and K. French (1993) "Common Risk Factors in the Returns on Stocks and Bonds," Journal of Financial Economics, vol. 33 (February), p. 3-56.

32. Fama, E. and K. French (1995) "Size and Book-to-Market Factors in Earnings and Returns," Journal of Finance, vol. 50 (March), p. 55-84.

33. Forbes Magazine Forbes Compensation 800 List. Forbes Magazine. May Issues. 1997-2006. 
34. Gabaix, X and A. Landier (2008) "Why has CEO Pay Increased so Much,” The Quarterly Journal of Economics, vol. 123(1), p. 49-100.

35. Gibbons, R. and K.J. Murphy. 1992. Optimal Incentive Contracts in the Presence of Career Concerns: Theory and Evidence. Journal of Political Economy. v. 100(3) p. 468-505.

36. Gottesman, Aron A. and M. R. Morey (2006) "Does a Better Education Make For Better Managers? An Empirical Examination of CEO Educational Quality and Firm Performance," (April 21, 2010). Available at SSRN: ssrn.com/abstract $=564443$

37. Hamada, R.S. 1972. "The Effect of the Firm's Capital Structure on the Systematic Risk of Common Stocks, Journal of Finance vol. 27(May) p. 435-452.

38. Harris M., and A. Raviv. 1991. The Theory of Capital Structure. Journal of Finance, vol. 46 (March) p. 297-355.

39. Hambrick, D.C. and P.P. Mason (1984) "Upper Echelons: The Organization as a Reflection of its Top Managers," Academy of Management Review," vol. 2, p. 193-206.

40. He, Lerong (2008) "Do Founders Matter? A Study of Executive Compensation, Governance Structure and Firm Performance, Journal of Business Venturing, vol. 23(3), p. 257-279

41. Hermalin, B.E. and N.E. Wallace. 2001. Firm Performance and Executive Compensation in the Loan Industry. Journal of Financial Economics. v. 36, 405-31.

42. Hermalin, B. (2005) “Trends in Corporate Governance," Journal of Finance vol. 60, p. 2351-2384.

43. Jalbert, T. 2002. Pass-Through Taxation and the Value of the Firm. The American Business Review. V. 20(2) 47-54

44. Jalbert, Terrance and Mercedes Jalbert (2005) "Founders versus non-founders: An Empirical Analysis of CEO Educational Background" Review of Business Research Vol. V(1), p. 87-100

45. Jalbert, Terrance, Mercedes Jalbert and Gino Perrina (2004) "Does Degree Matter? An Empirical Analysis of CEO Educational Paths," Journal of College Teaching and Learning Vol. 5(1) May p. 65-73

46. Jalbert, Terrance, Ramesh Rao, and Mercedes Jalbert (2002) "Does School Matter? An Empirical Analysis of CEO Education, Compensation and Firm Performance," International Business and Economics Research Journal, Vol. 1(1) Winter, p. 83-98

47. Jensen, M.C. (1986a) "Agency Costs of Free Cash Flow, Corporate Finance and Takeovers," American Economic Review, vol. 76 (May), 323-329

48. Jensen, M.C. (1986b) "The Takeover Controversy: Analysis and Evidence," The Midland Corporate Finance Journal, Summer, 6-32.

49. Jensen, M. and W. Meckling. 1976. Theory of the Firm: Managerial Behavior, Agency Costs and Capital Structure. Journal of Financial Economics. 3, 305-60.

50. Jensen, M.C. and K.J. Murphy (1990) "Performance Pay and Top Management Incentives," Journal of Political Economy, vol. 98, p. 225-264.

51. John, K. A. Saunders and L. Senbet. 2000. A Theory of Bank Regulation and Management Compensation. Review of Financial Studies. v. 13, 95-125.

52. John, T.A. and K. John. 1993. Top-Management Compensation and Capital Structure. Journal of Finance. v. 48, 949-74.

53. Joskow,P.L., N.L. Rose and A. Shephard (1993) "Regulatory Constraints on CEO Compensation," Brookings Papers on Economic Activity, Microeconomics (1993) p. 1-72

54. Joskow, Paul L. Nancy L. Rose and Catherine D. Wolfram (1996) "Political Constraints on Executive Compensation: Evidence from the Electric Utility Industry," RAND Journal of Economics vol. 27(1, spring) p. 165-182.

55. Kato, Takao and Rockel, Mark (1992b). "The Importance of Company Breeding in the U.S and Japanese Managerial Labor Markets: A Statistical Comparison.” Japan and The World Economy Vol. 4, p. 39-45.

56. Lucier, C., R. Schuyt and R. Spiegel. 2003. Performance-Related Dismissals Are Up and Board Tolerance is Down at Large Companies Around The World: the Annual Booz Allen Hamilton Study. Strategy \& Business Magazine. May

57. Miller, M. 1977. Debt and Taxes. Journal of Finance. May, 261-75

58. Miller, M. and F. Modigliani. 1961. Dividend Policy, Growth and the Valuation of Shares. Journal of Business. v. 34(October) 411-33

59. Modigliani, F., and M. Miller. 1958. The Cost of Capital, Corporation Finance, and the Theory of Investment. American Economic Review. June, 261-97 
60. Modigliani, F., and M. Miller. 1963. Corporate Income Taxes and the Cost of Capital. American Economic Review. June, 433-43.

61. Murphy, Kevin J. (1985) "Corporate Performance and Managerial Remuneration: An Empirical Analysis," Journal of Accounting and Economics, vol. 7(April), p. 11-42.

62. Murphy, K. 2003. Stock-Based Pay in New Economy Firms. Journal of Accounting and Economics, v. 34, $129-47$

63. Murphy, K. and B. Hall. 2002. Stock Options for Undiversified Executives. Journal of Accounting and Economics. v. 33(1, February), 3-42

64. Murphy, Kevin and Jerold L. Zimmerman. (1993) "Financial Performance Surrounding CEO Turnover." Journal of Accounting and Economics, Vol. 16, p. 273-315.

65. Palia, D. and A. Ravid. 2002. The Role of Founders in Large Companies: Entrenchment or Valuable Human Capital? Working Paper.

66. Palia, D. (2000) “The Impact of Regulation on CEO Labor Markets," RAND Journal of Economics, vol. 31(1, Spring), p. 165-179.

67. Palia, Darius, S. Abrham Ravid and Chia Jane Wang (2008) "Founders versus non-founders in Large Companies: Financial Incentives and the Call for Regulation," Journal of Regulatory Economics, vol. 33(1, February), p. 55-86.

68. Pennathur, A.K. and R.M. Shelor (2002) "The Determinants of REIT CEO Compensation," The Journal of Real Estate Finance and Economics, vol. 25(1) p. 99-113.

69. Plitch, P. 2005. Founder's Fee. The Wall Street Journal. April 11, p. R4

70. Prendergast, C. 2002. The Tenuous Trade-off Between Risk and Incentives. Journal of Political Economy. v. 110, 1071-1102

71. Rajagopalan, Nandini, and D.K. Datta (1996) “CEO Characteristics: Does Industry Matter?” Academy of Management Journal, vol. 39(1) p. 197-215.

72. Reinganum, M. 1981. Misspecification of Capital Asset Pricing: Empirical Anomalies Based on Earnings Yields and Market Values. Journal of Financial Economics. v. 9 (March) 19-46

73. Roach, G. and A. Goedde. 2003. CEO Compensation in the Pharmaceutical Industry. Compensation Benefits Review. v. 35, 66-81

74. Sundaram, Rangarjan K. and David L. Yermack (2007) "Pay Me Later: Inside Debt and Its Role in Managerial Compensation," Journal of Finance, vol. 62(4) p. 1551-1588.

75. Thomas, Susan A., and Peyrefitte, Joseph (1996). "The Impact of Managerial Discretion on Firm Performance.” Journal of Business Strategies Vol. 13(1). p. 21-41

76. Tsui, A.S., T.D. Egan and C.A. O'Reilly (1989) "Beyond Simple Demographic Effects: The Importance of Relational Demography in Superior-subordinate Dyads," Academy of Management, vol. 32, p. 402-423.

77. Westphal, J.D. and E.J. Zajac (1995) "Who Shal Govern? CEO/Board Power, Demographic Similarity and New Director Selection," Administrative Science Quarterly vol. 40, p. 60-83.

78. Wiersema, M. F., and K. A. Bantel. 1992. "Top Management Team Demography and Corporate Strategic Change." Academy of Management Journal 35: 91-121. 
NOTES 